NASA Technical Memorandum 106434

AIAA-94-0218

\title{
CFD Assessment of Orifice Aspect Ratio and Mass Flow Ratio on Jet Mixing in Rectangular Ducts
}

D.B. Bain and C.E. Smith

CFD Research Corporation

Huntsville, Alabama

and

J.D. Holdeman

Lewis Research Center

Cleveland, Ohio

Prepared for the

32nd Aerospace Sciences Meeting and Exhibit

sponsored by the American Institute of Aeronautics and Astronautics

Reno, Nevada, January 10-13, 1994 


\title{
CFD Assessment of Orifice Aspect Ratio and Mass Flow Ratio on Jet Mixing in Rectangular Ducts
}

\author{
D. B. Bain ${ }^{*}$ and C. E. Smith** \\ CFD Research Corporation \\ Huntsville, Alabama \\ J. D. Holdeman ${ }^{* * *}$ \\ NASA Lewis Research Center \\ Cleveland. Ohio
}

\begin{abstract}
$\underline{\text { Abstract }}$
Isothermal CFD analysis was performed on axially opposed rows of jets mixing with crossflow in a rectangular duct. Laterally, the jets' centerlines were aligned with each other on the top and bottom walls. The focus of this study was to characterize the effects of orifice aspect ratio and jet-to-mainstream mass flow ratio on jet penetration and mixing. Orifice aspect ratios (L/W) of 4-to-1, 2-to-1, and 1-to-1, along with circular holes, were parametrically analyzed. Likewise, jet-to-mainstream mass flow ratios (MR) of 2.0, 0.5, and 0.25 were systematically investigated. The jet-tomainstream momentum-flux ratio $(J)$ was maintained at 36 for all cases, and the orifice spacing-to-duct height $(\mathrm{S} / \mathrm{H})$ was varied until optimum mixing was attained for each configuration.

The numerical results showed that orifice aspect ratio (and likewise orifice blockage) had little effect on jet penetration and mixing. Based on mixing characteristics alone, the 4-to-1 slot was comparable to the circular orifice. The 4-to- 1 slot has a smaller jet wake which may be advantageous for reducing emissions. However, the axial length of a 4-to-1 slot may be prohibitively long for practical application,
\end{abstract}

especially for MR of 2.0. The jet-to-mainstream mass flow ratio had a more significant effect on jet penetration and mixing. For a 4-to-1 aspect ratio orifice, the design correlating parameter for optimum mixing $[\mathrm{C}=(\mathrm{S} / \mathrm{H}) \sqrt{\mathrm{J}}]$ varied from 2.25 for a mass flow ratio of 2.0 to 1.5 for a mass flow ratio of 0.25 .

\section{Nomenclature}

$\begin{array}{ll}\mathrm{C} & (\mathrm{S} / \mathrm{H}) \sqrt{\mathrm{J}} \quad \text { (see Eq. 1) } \\ \mathrm{C}_{\mathrm{avg}} & \mathrm{m}_{\mathrm{j}} /\left(\mathrm{m}_{\mathrm{j}}+\mathrm{m}_{\infty}\right)=\theta_{\mathrm{EB}} \\ \mathrm{H} & \text { Duct Height } \\ \mathrm{J} & \text { Momentum-Flux Ratio }\left(\rho_{\mathrm{j}} \mathrm{V}_{\mathrm{j}}^{2}\right) /\left(\rho_{\infty} \mathrm{U}_{\infty}^{2}\right) \\ \mathrm{L} & \text { Orifice Length (long dimension) } \\ \mathrm{L} / \mathrm{W} & \text { Orifice Aspect Ratio (SAR in previous reports) } \\ \mathrm{m}_{\mathrm{j}} & \text { Mass Flow of Jets } \\ \mathrm{m}_{\infty} & \text { Mass Flow of Mainstream } \\ \mathrm{MR} & \text { Mass Flow Ratio } \mathrm{m}_{\mathrm{j}} / \mathrm{m}_{\infty} \\ \mathrm{P} & \text { Pressure }\left(\mathrm{N} / \mathrm{m}^{2}\right) \\ \mathrm{S} & \text { Orifice Spacing } \\ \mathrm{S} / \mathrm{H} & \text { Orifice Spacing-to-Duct Height Ratio } \\ \mathrm{T} & \text { Temperature (K) } \\ \mathrm{U}_{\infty} & \text { Mainstream Flow Velocity (m/s) } \\ \mathrm{U} & \text { Unmixedness (see Eq. 2) } \\ \mathrm{u} & \text { rms of Axial Velocity Fluctuation }\end{array}$

* $\quad$ Project Engineer, Member AIAA

** Vice President/Engineering, Member AIAA

*** Senior Research Engineer, Associate Fellow AIAA 
v rms of Vertical Velocity Fluctuation

W Orifice Width (short dimension)

$x$ Axial Coordinate, $x=0$ at leading edge of the orifice

$\mathrm{x} / \mathrm{H} \quad$ Axial Distance-to-Duct Height Ratio

$\mathrm{V}_{\mathrm{j}} \quad$ Jet Velocity $(\mathrm{m} / \mathrm{s})$

y Vertical Coordinate

z Lateral Coordinate

$\mu_{\mathrm{T}} \quad$ Turbulent Viscosity $(\mathrm{kg} / \mathrm{m} \cdot \mathrm{sec})$

$\rho_{\mathrm{j}} \quad$ Density of Jet

$\rho_{\infty} \quad$ Density of Mainstream

\section{Introduction}

In recent years increased public awareness on issues such as global warming and upper atmosphere ozone depletion have sparked a growing concern over the environment. Despite the ever tightening emissions regulations, the vast majority of upper atmosphere pollutants still originate from combustion systems. To meet the increasing stringent air quality standards, low emission combustors must be developed.

One such concept being evaluated both experimentally and numerically is the Rich-burn/Quick-mix/Lean-burn (RQL) combustor ${ }^{1}$. This combustor utilizes staged burning in which the primary zone is designed to operate fuel rich at equivalence ratios exceeding one. ${ }^{2}$ The combustion products high in carbon monoxide concentration enter the quick-mix section where mixing is initiated with bypass air. The combustion process is then completed in the lean-burn region.

In order to make the RQL combustor a viable combustor concept for low emissions, rapid and uniform mixing must take place in the quick-mix section. Recent studies have been performed that focus on identifying improved mixing concepts. ${ }^{3-17}$

\section{Background}

The mixing of jets in a confined crossflow has proven to have far reaching practical applications and has spurred a variety of research studies over the last quarter of a century. In gas turbine combustors, jet mixing is particularly important in the combustor dilution zone. The dilution zone is the aft zone where the products of combustion are mixed with air to produce a temperature profile acceptable to the turbine. ${ }^{18-20}$

Dilution zone mixing studies ${ }^{18}$ have identified two significant design parameters that influence the mixing pattern: 1) jet-to-mainstream momentum-flux ratio $(\mathrm{J})$ and 2 ) orifice spacing-to-duct height ratio $(\mathrm{S} / \mathrm{H})$. Optimum mixing relationships were determined to be a function of the product of $\mathrm{S} / \mathrm{H}$ and square root of $\mathrm{J}$ for the range of conditions tested and analyzed:

$$
\mathrm{C}=(\mathrm{S} / \mathrm{H}) \sqrt{\mathrm{J}}
$$

One-sided injection (from the top wall only) and twosided injection (from both the top and bottom walls) were studied. The optimum mixing constants were identified as shown in Table 1. For two-sided, axially opposed rows of jets with jets' centerlines aligned, optimum mixing was obtained when $\mathrm{C}$ was 1.25 . The best mixing occurred when the dilution jets penetrated to about one-quarter duct height.

In contrast to conventional dilution zones, the quickmix section of RQL combustors has a larger jet-tomainstream mass flow ratio $(M R \geq 2.0$ vs. $\leq 0.5)$. Such a large MR for RQL combustors might necessitate the use of slots rather than holes in the combustor liner. It is unclear whether orifice aspect ratio affects jet mixing, especially at large mass flow ratios. It is also unclear if design correlations developed for $M R<0.5$ are applicable to large $M R(\geq 2.0)$. This study sought to address these issues by a systematic computational investigation. A complete description of the cases studied and their results are discussed below.

\section{CFD Code}

The approach in this study was to perform 3-D numerical calculations on a generic geometry section. 
The CFD code named CFD-ACE ${ }^{21}$ was used to perform the computations. The basic capabilities/methodologies in CFD-ACE include:

(1) co-located, fully implicit and strongly conservative finite volume formulation;

(2) solution of two- and three-dimensional NavierStokes equations for incompressible and compressible flows;

(3) non-orthogonal curvilinear coordinates;

(4) multi-domain grid topology;

(5) upwind, central (with damping), second order upwind and Osher-Chakravarthy differencing schemes;

(6) standard $^{22}$, extended ${ }^{23}$, and low Reynolds number ${ }^{24} \mathrm{~K}-\varepsilon$ turbulence models;

(7) instantaneous, one-step, and two-step heat release and emission combustion models;

(8) spray models including trajectory, vaporization, etc.; and

(9) pressure-based solution algorithms including SIMPLE and a variant of SIMPLEC.

\section{Details of Numerical Calculations}

A schematic of the computational model is shown in Figure 1. The height of the mixing section was 4 inches $(0.1016 \mathrm{~m})$. The mainstream flow entered the calculation domain one duct height upstream $(x / H$ of $-1.0)$ of the leading edge of the orifices, and continued downstream to $x / H$ of 7.0 . The model consisted of jet injection from top and bottom walls into mainstream flow. Three siot orifices were analyzed, having aspect ratios of 4-to-1, 2-to-1, and 1-to-1. A circular orifice was also analyzed for completeness. The slots were aligned with the long dimension in the direction of the mainstream flow.

The rows of orifices located on the top and bottom walls were in the same axial plane and inline in the lateral direction. The lateral calculation domain extended from midplane to midplane between the jets' centerlines. Periodic boundary conditions were imposed on the lateral boundaries.

Six parametrics consisting of 31 cases were analyzed as shown in Table 2. The case sequence for each parametric consisted of holding J, MR, and L/W constant, and then parametrically changing $\mathrm{S} / \mathrm{H}$ to optimize mixing. As $\mathrm{S} / \mathrm{H}$ was varied, the slot dimensions changed to maintain a constant jet-tomainstream mass flow ratio. For each parametric, the slot geometry producing optimum mixedness is shown in Figure 2. Parametrics 1,2, and 3 show the effect of MR. A 4-to-1 slot orifice was held constant in parametrics 1,2 , and 3. Parametrics $1,4,5$, and 6 show the effect of orifice aspect ratio. The mass flow ratio was held constant at 2.0 for parametrics $1,4,5$, and 6.

The flow conditions of the mainstream and jets were

$$
\begin{aligned}
& \text { Mainstream } \quad \underline{\text { Jets }} \\
& \mathrm{U}_{\infty}=10 \mathrm{~m} / \mathrm{s} \quad \mathrm{V}_{\mathrm{j}}=60 \mathrm{~m} / \mathrm{s} \\
& \mathrm{T}_{\infty}=300 \mathrm{~K} \quad \mathrm{~T}_{\mathrm{j}}=300 \mathrm{~K} \\
& \mathrm{u} / \mathrm{U}_{\infty}=0.20 \quad \mathrm{v} / \mathrm{v}_{\mathrm{j}}=0.20 \\
& \mu_{\mathrm{T}}=\underset{\mathrm{kg} / \mathrm{m} \cdot \mathrm{sec}}{1 \times 10^{-2}} \quad \mu_{\mathrm{T}}=1 \times 10^{-2} \\
& \mathrm{P} \quad=1 \times 10^{5} \mathrm{~N} / \mathrm{m}^{2} \\
& \mathrm{~J}=36 \\
& \mathrm{~m}_{\mathrm{j}} / \mathrm{m}_{\infty}=2.0,0.50,0.25
\end{aligned}
$$

The turbulent length scales of the jets were varied to maintain a constant inlet turbulent viscosity.

\section{Grids}

A typical case consisted of 60,000 cells, 64 cells in the axial ( $x$ ) direction, 28 cells in the vertical (y) direction, and 34 cells in the lateral (z) direction. The slots were composed of uniformly distributed cells; 192 cells ( $24 \times 8$ ) for the $4: 1$ slot, 384 cells $(24 \times 16)$ for the $2: 1$ slot, and 528 cells $(24 \times 24)$ for the 1:1 slot. The circle was generated using boundary fitted coordinates and was 
composed of 576 cells. The grid upstream and downstream of the orifice region was expanded/contracted so that each cell adjacent to the slot region matched the cell size in the slot region. The cells in the vertical direction were all of uniform size.

\section{Numerics}

The following conservation equations were solved: u momentum, $v$ momentum, $w$ momentum, mass (pressure correction), turbulent kinetic energy (k), and turbulent energy dissipation $(\varepsilon)$. The convective fluxes were calculated using upwind differencing, and the diffusive fluxes were calculated using central differencing. The standard $k-\varepsilon$ turbulence model was employed and conventional wall functions were used.

\section{Convergence}

All error residuals were reduced at least 6 orders of magnitude, and continuity was conserved in each axial plane to the fifth decimal. Convergence was relatively smooth requiring about 600 iterations. A converged solution required approximately $4.0 \mathrm{CPU}$ hours on a CRAY-YMP computer.

\section{Data Postprocessing}

Graphics postprocessing was performed using NASA PLOT3D software. ${ }^{25}$ The only exception was Figure 11 which was processed using CFD-VIEW. ${ }^{26,27}$

In order to quantify the mixing effectiveness, the massaveraged spatial concentration variance of jet flow $\left(\mathrm{C}_{\mathrm{var}}\right)$ was calculated in each axial plane. The mass-averaged unmixedness $(U)$ is defined ${ }^{28}$ as

$$
\mathrm{U}=\mathrm{C}_{\mathrm{var}} /\left[\mathrm{C}_{\mathrm{avg}}\left(1-\mathrm{C}_{\mathrm{avg}}\right)\right]
$$

where

$$
\begin{array}{ll}
\mathrm{C}_{\mathrm{var}} & =\left(1 / \mathrm{m}_{\mathrm{TOT}}\right) \sum_{\mathrm{i}} \mathrm{m}_{\mathrm{i}}\left(\mathrm{C}_{\mathrm{i}}-\mathrm{C}_{\mathrm{avg}}\right)^{2} \\
\mathrm{~m}_{\mathrm{TOT}} & =\text { total mass flow in each axial plane } \\
\mathrm{m}_{\mathrm{i}} & =\text { mass flow of cell } i \\
\mathrm{C}_{\mathrm{i}} & =\text { jet mass fraction in cell } i
\end{array}
$$

$$
\mathrm{C}_{\mathrm{avg}}=\mathrm{m}_{\mathrm{j}} /\left(\mathrm{m}_{\mathrm{j}}+\mathrm{m}_{\infty}\right)=\theta_{\mathrm{EB}}{ }^{17} \text { (downstream }
$$

Calculating the unmixedness parameter can be broken down into two parts: 1) in the orifice (jet injection) region, and 2) aft of the trailing edge of the orifice. Downstream of the orifice all of the jet flow has been added and $\mathrm{C}_{\mathrm{avg}}$ is a constant value as defined above. In the orifice region, $\mathrm{C}_{\mathrm{avg}}$ is calculated in each axial plane based on the amount of jet mass in that plane. The unmixedness curves show a sharp spike (just downstream of $x / H$ of 0 ) where the jet flow first enters the domain and then gradually drops as the jet flow begins to mix with the mainstream flow.

\section{Results and Discussion}

Figure 3 presents the unmixedness results for all of the parametrics. The optimum mixing curve for each parametric is illustrated by the bold line. Note that the inflection points in the unmixedness curves identify the location of the trailing edge of the orifice. Discussion of the results follows.

\section{Effect of Jet-to-Mainstream Mass Flow Ratio}

The effect of MR on jet penetration is presented in Figure 4. Plotted are the jet mass fraction color concentrations in a lateral plane through the orifice centerline. $\mathrm{S} / \mathrm{H}$ is held constant $(0.275)$ in the figure. The color bar distribution was the same for all three MR cases in Figure 4. Each color bar has an arrow signifying the overall jet mass fraction at equilibrium. It is hard to discern differences in jet penetration with this color bar since mixed-out (equilibrium) values of mass fraction vary significantly between MR cases. An alternate way to compare jet penetration is to alter the color bar distribution such that the color at mixed-out conditions is maintained for each MR case. Figure 5 is similar to Figure 4 but with the revised color bar for each MR case.

For the MR of 2.0 case, the jets are somewhat underpenetrated, allowing too much of the approach 
flow to pass through the center of the duct. In contrast, for MR of 0.25 , the jets are somewhat overpenetrated as evidenced by more mainstream flow being forced between the jets. For MR of 0.50, the jets have penetrated to $1 / 4$ duct height and an equal balance of mainstream flow has passed through the center of the duct and between the jets. Thus, a significant effect of MR on jet penetration is seen.

Figure 6 presents unmixedness results for each MR at the optimum $\mathrm{S} / \mathrm{H}$. Note that the optimum $\mathrm{S} / \mathrm{H}$ is 0.375 for MR of 2.0, while the optimum $\mathrm{S} / \mathrm{H}$ is 0.25 for $M R$ of 0.25 . Such a variation in optimum $S / H$ shows there is significant effect of $M R$ on unmixedness. In the orifice region, a large difference is seen between the different MR due to the large variation in orifice geometric size. Although the MR of 2.0 case exhibits the lowest value of unmixedness at the orifice leading edge, it has the highest value of unmixedness at $\mathrm{x} / \mathrm{H}$ between 0.3 and 0.5 because of the slot's length. For $x / H>0.7$, the MR of 2.0 case exhibits slightly better mixing than the other two MR cases.

Figure 7 presents the jet mass fraction contours in a lateral plane through the orifice centerline for each mass flow ratio. Figure 7 is similar to Figure 5 except the results are shown at optimum $\mathrm{S} / \mathrm{H}$ instead of constant $\mathrm{S} / \mathrm{H}$. Figure 8 presents the jet mass fraction contours for each mass flow ratio in an axial plane ( $\mathrm{x} / \mathrm{H}$ of 0.5 ). Optimum S/H cases are shown. At this axial location, the jets for the MR of 2.0 case are still entering the flowfield. For the other two MR cases, it can be seen there is equal balance of mainstream flow in the center of the duct and along the ducts' walls.

\section{Aspect Ratio Analysis}

The effect of aspect ratio variation on jet penetration is seen in Figure 9. Note that all cases have MR of 2.0. Presented are jet mass fraction concentrations in a lateral plane taken through the orifice centerline. $\mathrm{S} / \mathrm{H}$ was held constant $(0.425)$ in the figure. For each aspect ratio case, the jets penetrate approximately one-quarter of the duct height. There are some subtle differences between each aspect ratio case, the most recognizable being the difference between the square orifice (aspect ratio of 1to-1) and the other orifices. The square orifice appears to penetrate slightly less than the other orifices as evidenced by less mainstream flow in the wakes of the jets (less green behind jets). However, in general, aspect ratio has little effect on jet penetration.

Figure 10 provides insight into why the square jet has slightly less penetration than the other orifices. Figure 10 presents the jet mass fraction concentrations in a vertical plane next to the top wall. Compared to the 4-to-1 and 2-to-1 slot orifices, the square orifice presents significantly more blockage to the mainstream flow. The blockage of the square orifice is $63 \%$ as compared to $44 \%$ and $31 \%$ for the 2-to-1 and 4-to-1 slot orifices. If the orifice aspect ratio is further decreased, the mainstream flow would be almost totally blocked from passing between jets. Thus, the slight decrease in jet penetration for the square orifice case is probably caused by jet blockage effects. It is interesting to note that the circle orifice, although having larger frontal area (and jet blockage, $71 \%$ ), has less blockage effect on the mainstream flow than the square orifice. A possible cause of the reduced blockage effect of the circle is discussed in the next paragraph. It is interesting to note that Liscinsky ${ }^{15}$ has experimentally shown there is minimal effect of jet blockage for circle orifices having geometric blockages less than $75 \%$.

The effect of slot aspect ratio on jet wakes is illustrated in Figure 11. Figure 11 presents velocity vectors in the vertical plane next to the top wall. Near the wall the jet acts like a bluff body to the mainstream flow. The mainstream flow accelerates around the jet before separating and forming a wake behind the jet. As the base area of the orifice increases, the size of the wake recirculation zone increases. Thus, the square orifice has a wake width approximately twice that of the 4-to-1 slot. The wake width of the circle orifice is less than the wake width of the square orifice because the mainstream flow stays attached around the circular jet before separating. Such flow attachment may be the 
cause of slightly greater jet penetration of the circle compared to the square orifice. Wake sizes may have an impact on emissions in quick-mix strategies.

The effect on aspect ratio on unmixedness is illustrated in Figure 12. The unmixedness curves are presented at optimum $\mathrm{S} / \mathrm{H}$. In the orifice region there are sizable differences in the mixing between aspect ratios. The $4: 1$ slot had the best initial mixing followed by the $2: 1$, $1: 1$ and circle cases. Aft of the orifices' trailing edges, the different aspect ratio curves essentially yield the same level of unmixedness.

At $x / H$ of 0.5 , Figure 12 shows that the $4: 1$ slot is the most unmixed, while the 2:1 slot is the least unmixed, and the 1:1 slot and circle orifices are somewhere in between. Figure 13 gives insight into why the $4: 1$ slot is the most unmixed. Figure 13 shows the jet mass concentration contours of all four orifice shapes in an axial plane at $\mathrm{x} / \mathrm{H}$ of 0.5 . It can be seen that the $4: 1$ jets are still entering the flowfield at $\mathrm{x} / \mathrm{H}$ of 0.5 , resulting in a high degree of unmixedness. The most mixed appears to be the 2:1 slots and circle orifices.

Figure 14 shows a direct comparison of unmixedness for the 4-to-1 slot and circle cases. The optimum S/H for the slot is 0.375 while for the circle it is 0.425 , almost the same. Aft of the slot trailing edge $(x / H>0.5)$, the mixing levels of both orifices are identical. In the orifice region, there are some differences between orifices. At the orifice leading edge, the slot has less unmixedness than the circle, but aft of the circle trailing edge and upstream of the slot trailing edge, the circle case has less unmixedness than the slot case. From an overall unmixedness viewpoint, the circle and slot appear to be similar.

\section{Design Correlation Constant for Optimum Mixing}

Shown in Table 3 is a comparison of the design correlation constants $[(\mathrm{S} / \mathrm{H}) \sqrt{\mathrm{J}}]$ for optimum mixing. The constants are presented based on the numerical results of this study as well as based on previous experimental tests reported in the literature for low MR
$(<0.5)$. For MR of 2.0, the numerically determined constant was significantly higher than for the MR of 0.25 case ( 2.25 vs. 1.50 ). The design constant based on previous experiments was 1.25 for MR less than 0.5. Thus, there appears to be a significant mass flow ratio effect.

The constants were determined to be 2.25 for the $4: 1$ and $2: 1$ cases and 2.55 for the $1: 1$ and circle cases. The design constant of 2.55 for circles is in agreement with recent isothermal experiments by Liscinsky. ${ }^{15}$ Thus, in an engineering sense, the design constants were nearly the same for the four different orifice configurations. This result is consistent with the unmixedness and jet penetration results signifying little effect of aspect ratio.

\section{Conclusions}

A CFD parametric mixing study was performed on axially opposed rows of inline jets injected into a confined rectangular crossflow. Design variables systematically investigated were orifice aspect ratio (4to-1, 2-to-1, 1-to-1, and circle) and jet-to-mainstream mass flow ratio $(2.0,0.5$, and 0.25$)$. A constant jet-tomainstream momentum-flux ratio (J) of 36 was maintained for all simulations. Based on the numerical analysis, the following conclusions can be drawn:

1. Slot aspect ratio had little effect on jet penetration and mixing.

2. Circle and slot orifices had similar mixing characteristics.

3. The jet wake recirculation zone increased in size as slot aspect ratio decreased, as expected.

4. Jet-to-mainstream mass flow ratio influenced jet penetration and mixing. The design correlation constant $[\mathrm{C}=(\mathrm{S} / \mathrm{H}) \sqrt{J}]$ varied from 2.25 at a $M R$ of 2.0 to 1.5 for a MR of 0.25 . Previous experimental results had reported a design correlation constant of 1.25 for MR less than 0.5 . 


\section{Acknowledgement}

This work was supported by NASA Contract NAS325967 , and NAS computer time was provided by NASA Lewis Research Center. Valuable discussions and assistance were provided by Mr. Milind Talpallikar and Dr. Vincent Harrand. Our thanks are also extended to Ms. Kathy W. Rhoades for preparing this typescript.

\section{References}

1. R. J. Shaw, "Engine Technology Challenges for a 21st Century High Speed Civil Transport," AIAA Tenth International Symposium on Air Breathing Engines, September 1-6, 1991 (Also NASA TM 104363).

2. S. A. Mosier and R. M. Pierce, "Advanced Combustion Systems for Stationary Gas Turbine Engines," Vol. 1, EPA Contract 68-02-2136, 1980.

3. C. E. Smith, M. V. Talpallikar, and J. D. Holdeman, "A CFD Study of Jet Mixing in Reduced Flow Areas for Lower Combustor Emissions," AIAA 91-2460, June, 1991 (Also NASA TM 104411).

4. A. Vranos, D. S. Liscinsky, B. True, and J. D. Holdeman, "Experimental Study of Cross-Stream Mixing in a Cylindrical Duct," AIAA 91-2459, June, 1991 (Also NASA TM 105180).

5. M. V. Talpallikar, C. E. Smith, M. C. Lai, and J. D. Holdeman, "CFD Analysis of Jet Mixing in Low $\mathrm{NO}_{\mathrm{x}}$ Flametube Combustors," ASME Paper 91-GT-217, Vol. 114, pp. 416-424, ASME Transactions, Journal of Engineering for Gas Turbines and Power, 1992 (Also NASA TM 104466).

6. G. W. Howe, Z. Li, T. I.-P. Shih, and H. L. Nguyen, "Simulation of Mixing in the Quick Quench Region of a Rich Burn-Quick QuenchLean Burn Combustor," AIAA 91-0410, 1991.

7. M. S. Hatch, W. A. Sowa, G. S. Samuelsen, and J.D. Holdeman, "Jet Mixing Into a Heated Cross Flow in a Cylindrical Duct: Influence of
Geometry and Flow Variations," AIAA 92-0773, January 1992 (Also NASA TM 105390).

8. D. B. Bain, C. E. Smith, and J. D. Holdeman, "CFD Mixing Analysis of Jets Injected from Straight and Slanted Slots into Confined Crossflow in Rectangular Ducts," AIAA 923087, Nashville, TN, July 6-8, 1992 (Also NASA TM 105699).

9. D. S. Liscinsky, B. True, A. Vranos, and J. D. Holdeman, "Experimental Study of Cross-Stream Mixing in a Rectangular Duct," AIAA 92-3090, Nashville, TN, July 6-8, 1992 (Also NASA TM 106194).

10. V. L. Oechsle, H. C. Mongia, and J. D. Holdeman, "A Parametric Numerical Study of Mixing in a Cylindrical Duct," AIAA 92-3088, Nashville, TN, July 6-8, 1992 (Also NASA TM 105695).

11. G. Zhu and M.-C. Lai, "A Parametric Study of Penetration and Mixing of Radial Jets in NeckedDown Cylindrical Crossflow," AIAA 92-3091, Nashville, TN, July 6-8, 1992.

12. J. T. Kroll, W. A. Sowa, G. S. Samuelsen, and J. D. Holdeman, "Optimization of Circular Orifice Jets Mixing into a Heated Crossflow in a Cylindrical Duct," AIAA 93-0249, Reno, Nevada, January 11-14, 1993 (Also NASA TM 105984).

13. D. S. Liscinsky, A. Vranos, and R. P. Lohmann, "Experimental Study of Crossflow Mixing in Cylindrical and Rectangular Ducts," NASA CR 187141, March 1993.

14. Th. Doerr and D. K. Hennecke, "The Mixing Process in the Quenching Zone of the Rich-Lean Combustion Concept," AGARD $81^{\text {st }}$ Symposium on Fuels and Combustion Technology for Advanced Aircraft Engines, Colleferro, NR Rome, Italy, May 10-14, 1993.

15. D. S. Liscinsky, B. True, and J. D. Holdeman, "An Experimental Study of Crossflow Jet Mixing in Rectangular Ducts," AIAA-93-2037, Monterey, CA, June 28-30, 1993. 
16. D. B. Bain, C. E. Smith, and J. D. Holdeman, "CFD Mixing Analysis of Axially Opposed Rows of Jets Injected in Confined Crossflow," AIAA 93-2044, Monterey, CA, 1993 (Also NASA TM 106179).

17. V. L. Oechsle, H. C. Mongia, and J. D. Holdeman, "An Analytical Study of Jet Mixing in a Cylindrical Duct", AIAA 93-2043, Monterey, CA, June 28-30, 1993 (Also NASA TM 106181).

18. J. D. Holdeman, "Mixing of Multiple Jets with a Confined Subsonic Crossflow," Progress in Energy and Combustion Sciences, Vol. 19, pp. 31-70, 1993. (also NASA TM 104412, 1991 and AIAA 91-2458, 1991).

19. J. D. Holdeman, R. Srinivasan, R. Reynolds, and C. D. White, "Studies of the Effects of Curvature on Dilution Jet Mixing, Journal Propulsion and Power, Vol. 8, No. 1, p. 209, 1992. (Also, AIAA Paper 87-1953; NASA TM -89878 and AIAA Paper 88-3180; NASA TM-00896).

20. D. S. Crocker and C. E. Smith, "Numerical Investigation of Enhanced Dilution Zone Mixing in a Reverse Flow Gas Turbine Combustor," ASME 93-GT-129, 1993.

21. S. F. Owens, "CFD-ACE: Command Language Reference Manual," CFD Research Corporation, Huntsville, AL, CFDRC Report GR-92-6, 1992.
22. B. E. Launder and D. B. Spalding, "The Numerical Computation of Turbulent Flows," Computer Methods in Applied Mechanics and Engineering, Vol. 3, pp. 269-289, 1974.

23. Y. S. Chen and S. W. Kim, "Computation of Turbulent Flows Using an Extended $k-\varepsilon$ Turbulence Closure Model," NASA CR-179204, 1987.

24. K. Y. Chien, "Predictions of Channel and Boundary-Layer Flows with a Low-Reynolds Number-Turbulence Model," AIAA Journal, Vol. 23, No. 2, 1985.

25. P. P. Walatka, P. G. Buning, L. Pierce, and P. A. Elson, "PLOT3D User's Manual", NASA TM 101067, 1990.

26. V. J. Harrand, "CFD VIEW: A 3D Computer Graphics Software; Volume 1: Technical Manual," August 1992.

27. V. J. Harrand, "CFD VIEW: A 3D Computer Graphics Software; Volume 2: User's Manual," August 1, 1992.

28. P. V. Danckwertz, "The Definition and Measurement of Some Characteristics of Mixtures," Appl. Sci. Res., Sec. A, Vol. 3, pp. 279-296, 1952.

Table 1. Spacing and Momentum-Flux Ratio Relationships

\begin{tabular}{|l|c|}
\hline \multicolumn{1}{|c|}{ Configuration } & $\mathrm{C}=(\mathrm{S} / \mathrm{H}) \sqrt{(\mathrm{J})}$ \\
\hline Single-side injection: & $<1.25$ \\
Under-penetration & 2.5 \\
Optimum & $>5.0$ \\
Over-penetration & \\
& \\
Opposed rows of jets: & 1.25 \\
In-line optimum & 5.0 \\
Staggered optimum & \\
\hline
\end{tabular}


Table 2. Numerical Cases Analyzed

\begin{tabular}{|c|c|c|c|c|c|c|c|}
\hline Parametric & Case & $\frac{\text { Orifice }}{\text { Aspect }} \frac{\text { Ratio }}{}$ & $\frac{\text { Momentum }}{\text { Elux_Ratio }}$ & $\frac{\text { Mass Elow }}{\text { Ratio }\left(\mathbf{m}_{\mathrm{j}} / \mathbf{m}_{\mathrm{m}}\right)}$ & $\mathbf{S} / \mathbf{H}$ & $\underset{\text { Edge } X / H}{\text { Trailing }}$ & $\begin{array}{l}\text { Let } \\
\text { Blockage } \\
\text { at Wall }\end{array}$ \\
\hline Parametric 1 & $\begin{array}{l}\text { Case } 1 \\
\text { Case 2 } \\
\text { Case } 3 \\
\text { Case } 4 \\
\text { Case } 5 \\
\text { Case 6 } \\
\text { Case } 7 \\
\text { Case } 8 \\
\text { Case } 9 \\
\text { Case } 10 \\
\text { Case } 11\end{array}$ & $4: 1$ & $J=36$ & 2.0 & $\begin{array}{l}0.125 \\
0.20 \\
0.228 \\
0.25 \\
0.275 \\
0.325 \\
0.375^{*} \\
0.425 \\
0.50 \\
0.75 \\
1.0\end{array}$ & $\begin{array}{l}0.29 \\
0.36 \\
0.39 \\
0.41 \\
0.43 \\
0.47 \\
0.50 \\
0.53 \\
0.58 \\
0.71 \\
0.82\end{array}$ & \begin{tabular}{l|l}
57.7 & \\
45.6 & \\
42.8 & \\
40.8 & \\
38.9 & \\
35.8 & \\
33.3 & \\
31.3 & \\
28.9 & \\
23.6 & \\
20.4 &
\end{tabular} \\
\hline Parametric 2 & $\begin{array}{l}\text { Case } 12 \\
\text { Case } 13 \\
\text { Case } 14 \\
\text { Case } 15 \\
\text { Case } 16\end{array}$ & $4: 1$ & $\mathrm{~J}=36$ & 0.50 & $\begin{array}{l}0.125 \\
0.20 \\
0.250 \\
0.275^{*} \\
0.325\end{array}$ & $\begin{array}{l}0.14 \\
0.18 \\
0.20 \\
0.21 \\
0.23\end{array}$ & $\begin{array}{l}28.9 \\
22.8 \\
20.4 \\
19.5 \\
17.9\end{array}$ \\
\hline Parametric 3 & $\begin{array}{l}\text { Case } 17 \\
\text { Case } 18 \\
\text { Case } 19\end{array}$ & $4: 1$ & $\stackrel{J=36}{\downarrow}$ & $\stackrel{0.25}{\downarrow}$ & $\begin{array}{l}0.20 \\
0.25 * \\
0.275\end{array}$ & $\begin{array}{l}0.13 \\
0.14 \\
0.15\end{array}$ & $\begin{array}{l}16.1 \\
14.4 \\
13.8\end{array}$ \\
\hline Parametric 4 & $\begin{array}{l}\text { Case } 20 \\
\text { Case } 21 \\
\text { Case } 22 \\
\text { Case } 23 \\
\text { Case } 24\end{array}$ & $2: 1$ & $\mathrm{~J}=36$ & 2.0 & $\begin{array}{l}0.30 \\
0.375^{*} \\
0.425 \\
0.45 \\
0.50\end{array}$ & $\begin{array}{l}0.32 \\
0.35 \\
0.38 \\
0.39 \\
0.41\end{array}$ & $\begin{array}{l}52.7 \\
47.1 \\
44.3 \\
43.0 \\
40.8\end{array}$ \\
\hline Parametric 5 & $\begin{array}{l}\text { Case } 25 \\
\text { Case } 26 \\
\text { Case } 27 \\
\text { Case } 28\end{array}$ & $1: 1$ & $\mathrm{~J}=36$ & 2.0 & $\begin{array}{l}0.325 \\
0.375 \\
0.425^{*} \\
0.50\end{array}$ & $\begin{array}{l}0.23 \\
0.25 \\
0.27 \\
0.29\end{array}$ & $\begin{array}{l}71.6 \\
66.7 \\
62.6 \\
57.7\end{array}$ \\
\hline Parametric 6 & $\begin{array}{l}\text { Case } 29 \\
\text { Case } 30 \\
\text { Case } 31\end{array}$ & Circle-BFC & $\downarrow$ & $I^{2.0}$ & $\begin{array}{l}0.375 \\
0.425^{*} \\
0.50\end{array}$ & $\begin{array}{l}0.28 \\
0.30 \\
0.33\end{array}$ & $\begin{array}{l}75.2 \\
70.7 \\
65.1\end{array}$ \\
\hline
\end{tabular}

* represents Optimum Mixing Configuration 
Table 3. Experimentally ${ }^{18}$ and Numerically Determined Constants at Optimum S/H

\begin{tabular}{|c|c|c|c|c|c|c|c|}
\hline \multirow{2}{*}{ Geometry } & \multirow{2}{*}{$\begin{array}{l}\text { Lateral } \\
\text { Arrangement }\end{array}$} & \multirow{2}{*}{$\mathrm{m}_{\mathrm{j}} / \mathrm{m}_{\infty}$} & \multirow{2}{*}{$\begin{array}{l}\text { Aspect } \\
\text { Ratio }\end{array}$} & \multirow{2}{*}{$\mathrm{J}$} & \multirow{2}{*}{$\mathrm{S} / \mathrm{H}$} & \multicolumn{2}{|c|}{$\mathrm{C}=(\mathrm{S} / \mathrm{H}) \sqrt{\mathrm{J}}$} \\
\hline & & & & & & Experimental & Numerical \\
\hline \multirow[t]{6}{*}{ Two-Sided } & Inline & 2.0 & $4: 1$ & 36 & 0.375 & 1.25 & 2.25 \\
\hline & & 0.5 & & & 0.275 & & 1.65 \\
\hline & & 0.25 & $\forall$ & & 0.25 & & 1.50 \\
\hline & & 2.0 & $2: 1$ & & 0.375 & & 2.25 \\
\hline & & & $1: 1$ & & 0.425 & & 2.55 \\
\hline & $\downarrow$ & $\downarrow$ & Circle & $\downarrow$ & 0.425 & $\vee$ & 2.55 \\
\hline
\end{tabular}




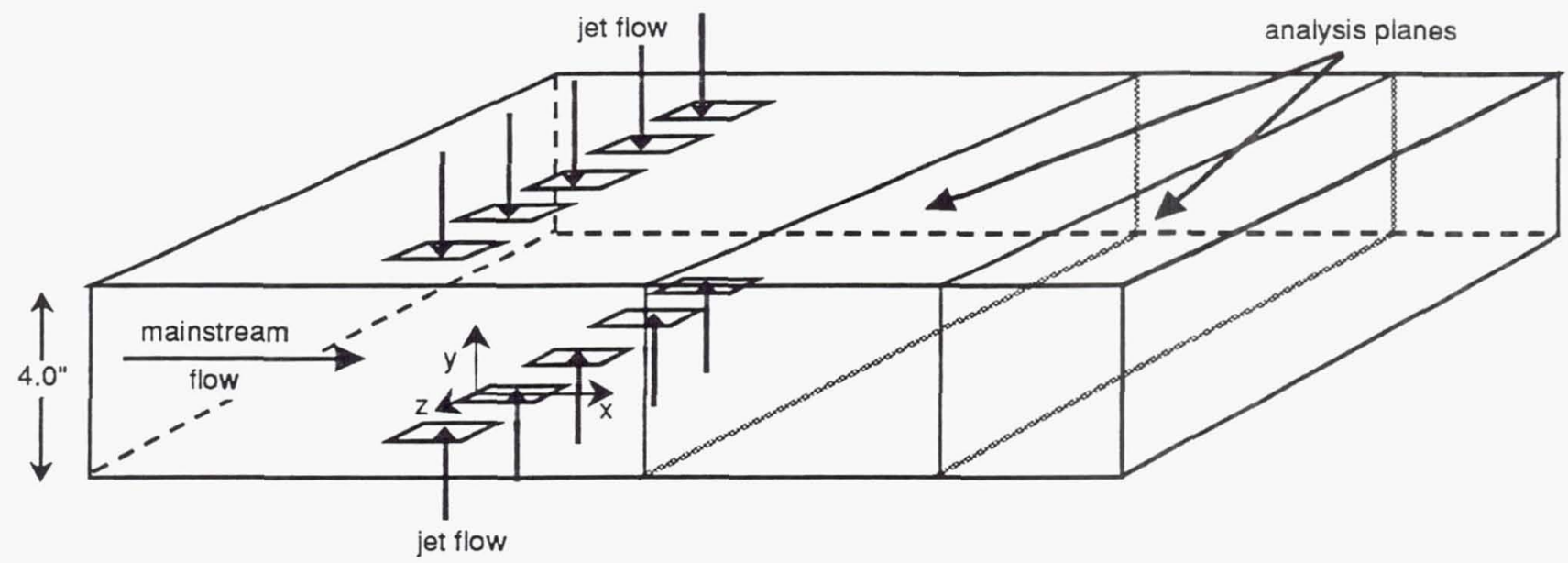

Figure 1. Schematic of Numerical Mixing Model
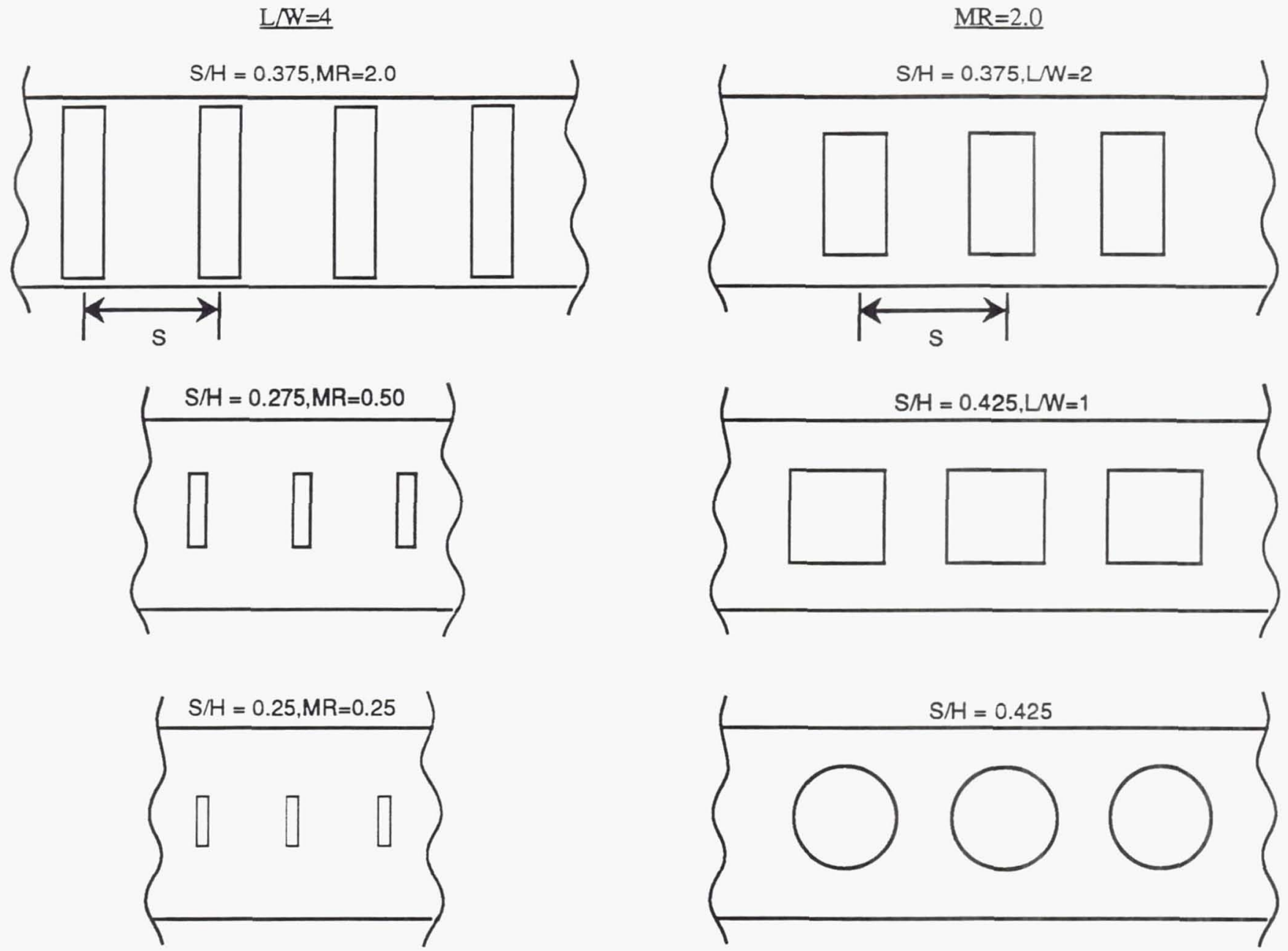

Figure 2. Slot Configurations At Optimum S/H 

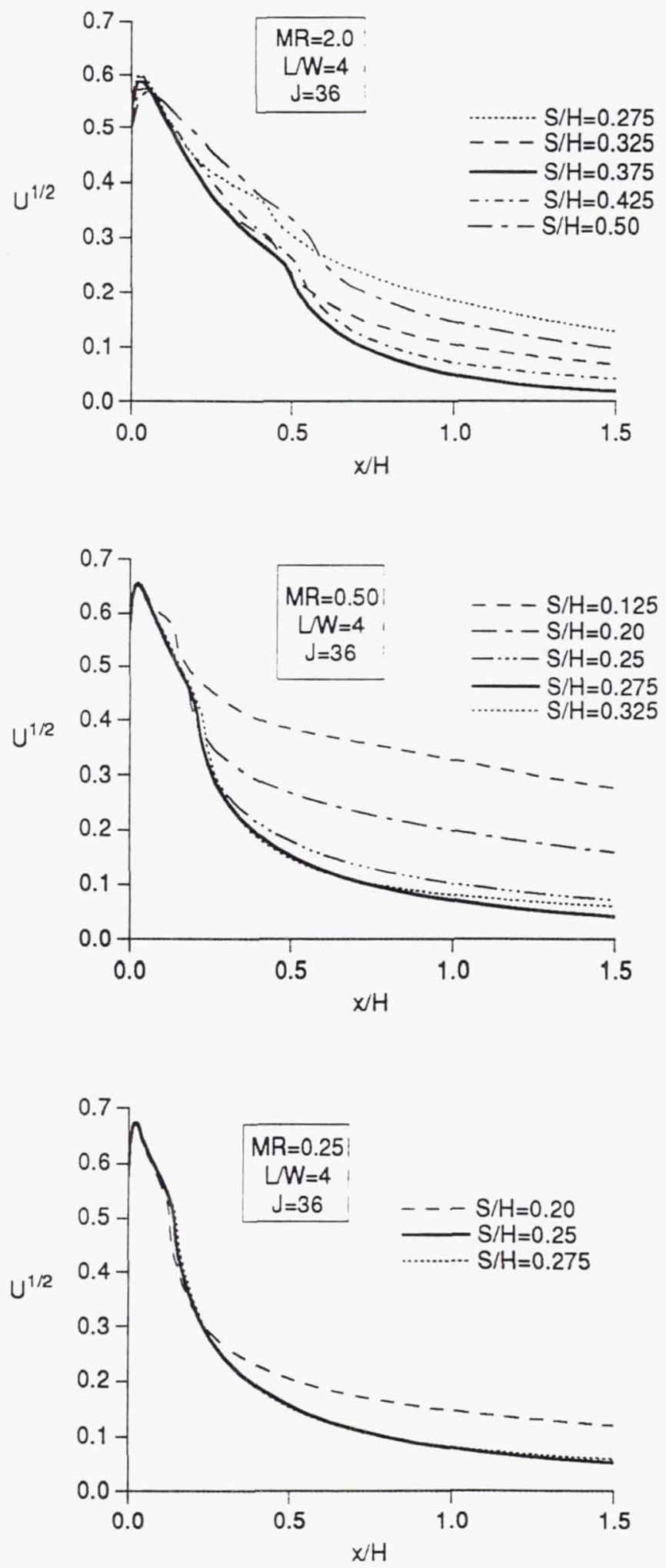

Figure 3. Computational Results of Parametrics 1-3 

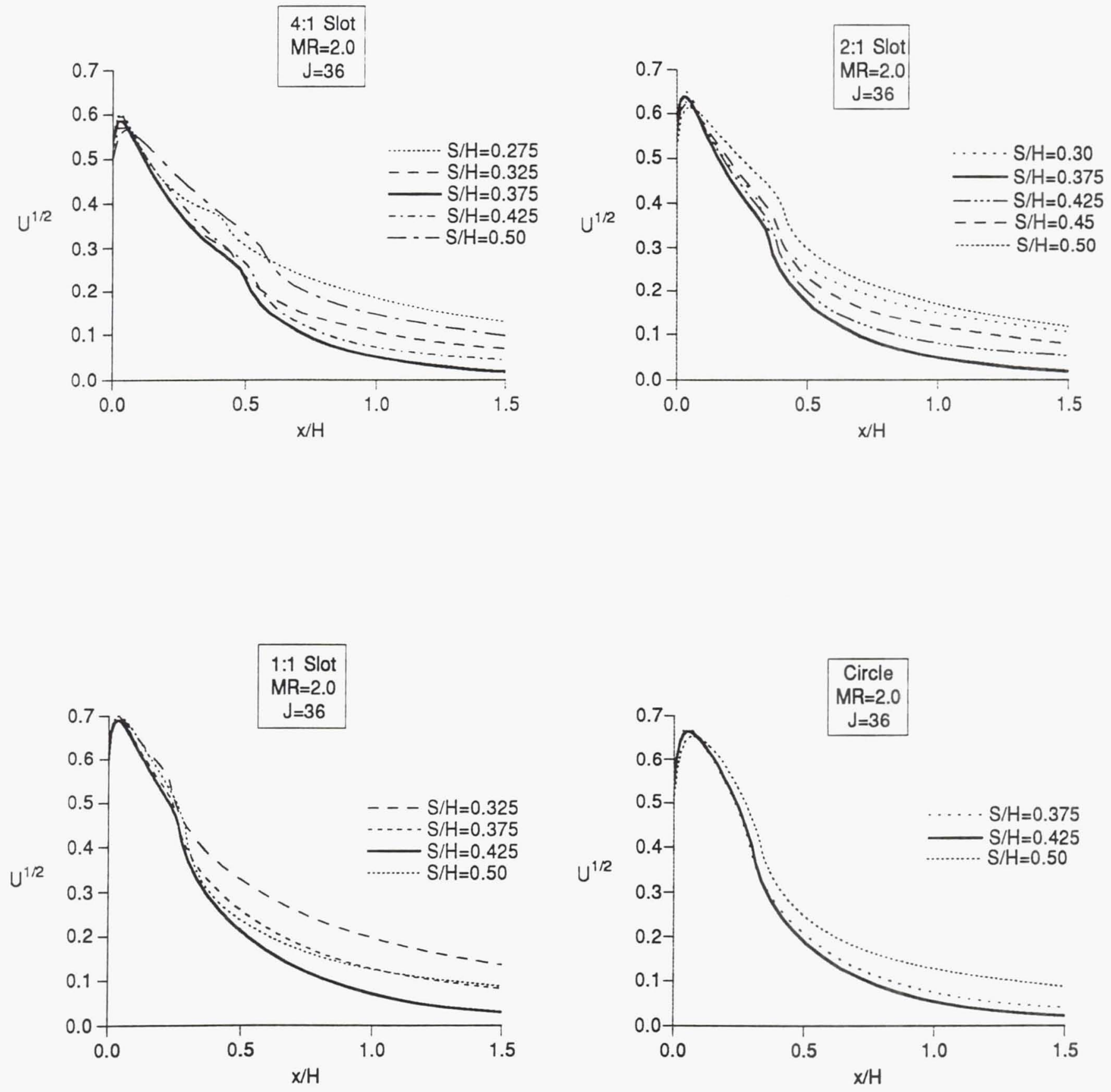

Figure 3. Computational Results of Parametrics 1, 4, 5, and 6 (cont'd) 


\section{Slot Centerline@S/H=0.275}

\section{MR}

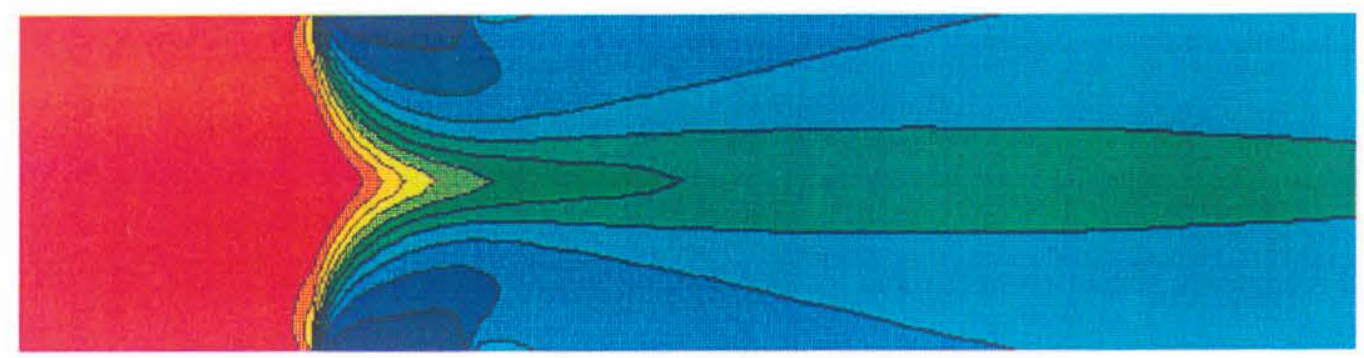

2.0

Jet

\section{Mass}

Fraction

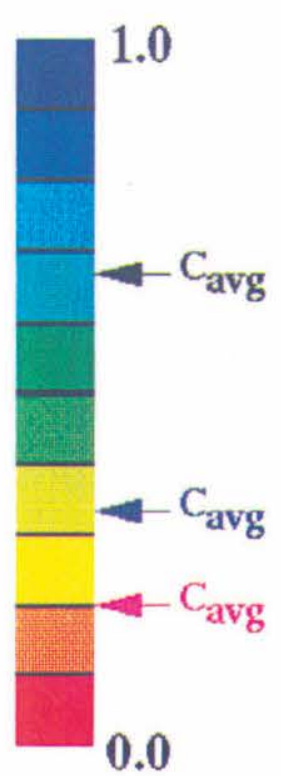

$$
C_{\text {avg }}=0.66
$$

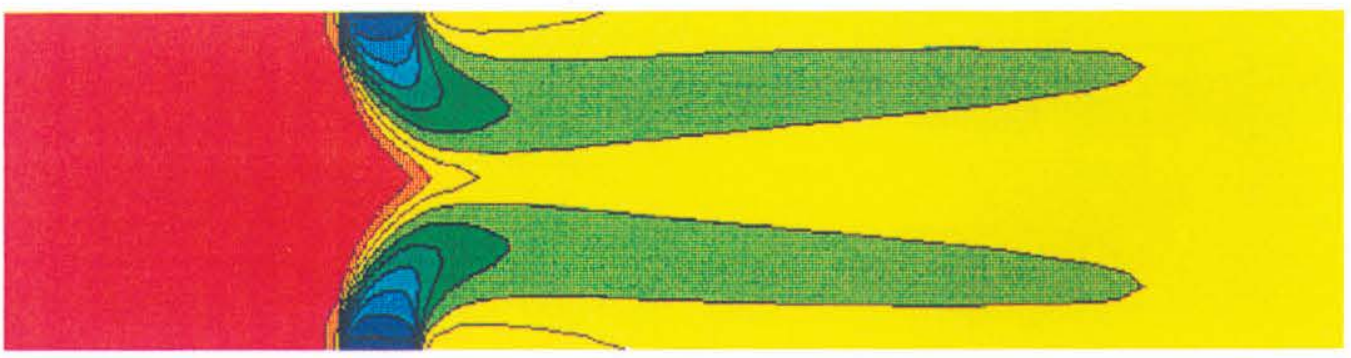

$$
\mathrm{C}_{\text {avg }}=0.33
$$

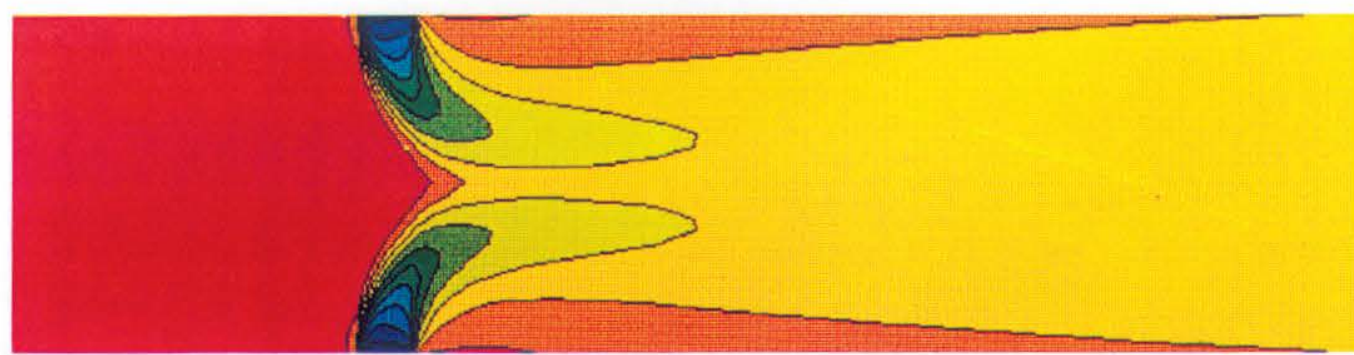

$$
\mathrm{C}_{\text {avg }}=0.20
$$

Figure 4. Effect of Jet-to-Mainstream Mass Flow Variation on Jet Penetration: J=36, L/W=4 (Uniform Color Bar Distribution) 


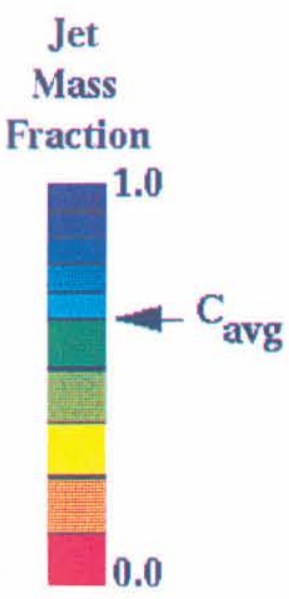

\section{Slot Centerline@S/H=0.275}

\section{MR}

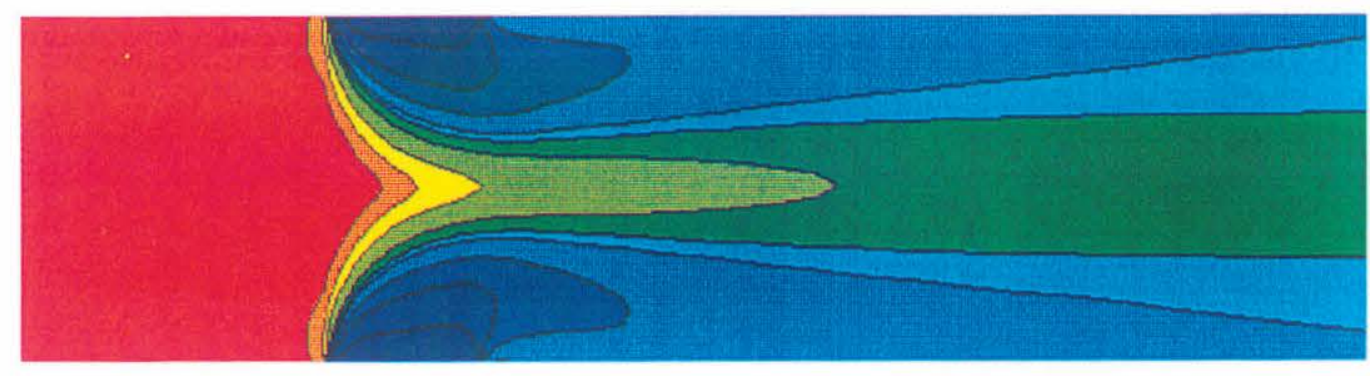

2.0

0.50
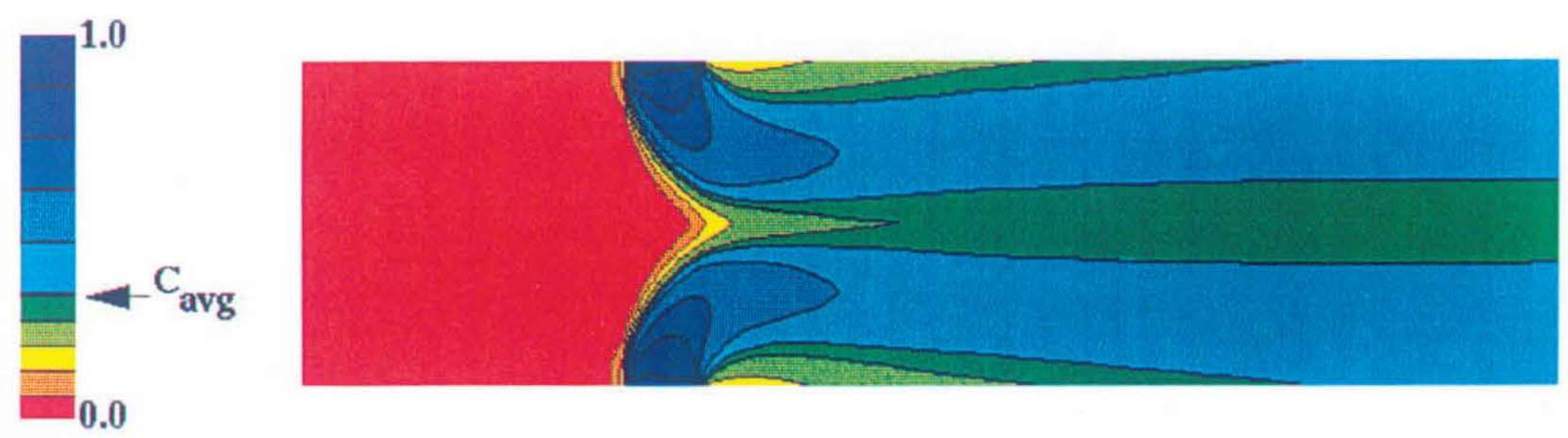

0.25
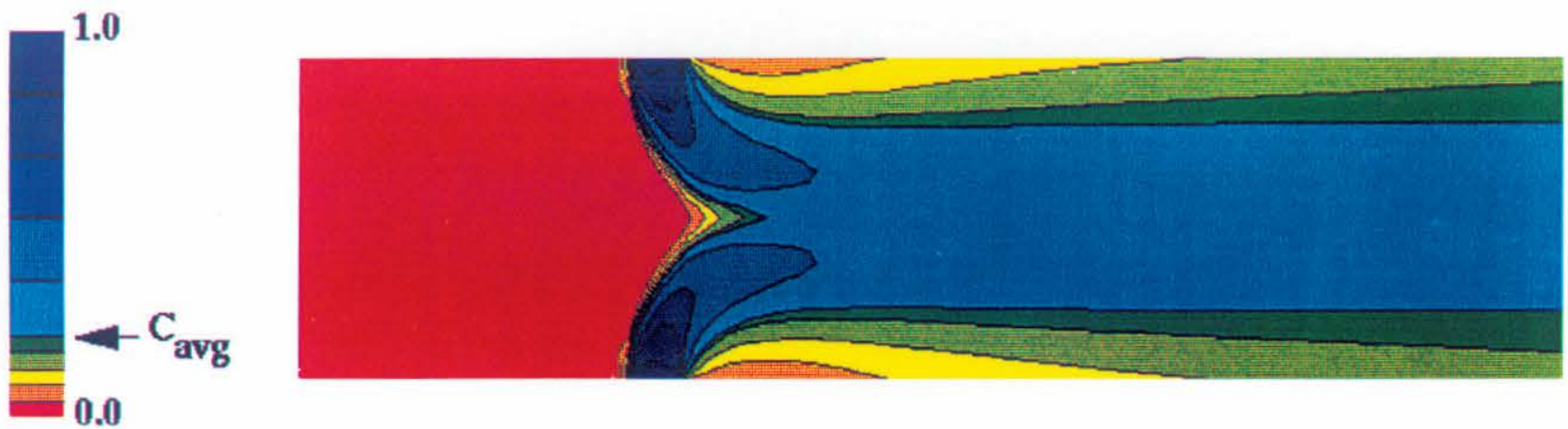

Figure 5. Effect of Jet-to-Mainstream Mass Flow Variation on Jet Penetration: J=36, L/W=4 (Non-uniform Color Bar Distribution) 


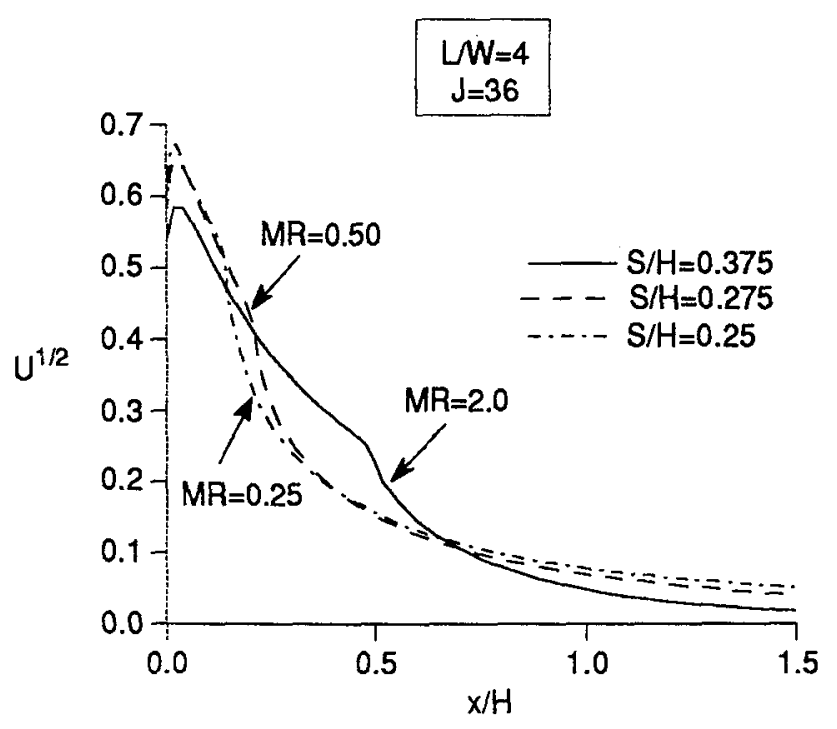

Figure 6. Effect of Jet-to-Mainstream Mass Flow Ratio on Unmixedness at Optimum S/H 


\section{Slot Centerline@Optimum S/H}
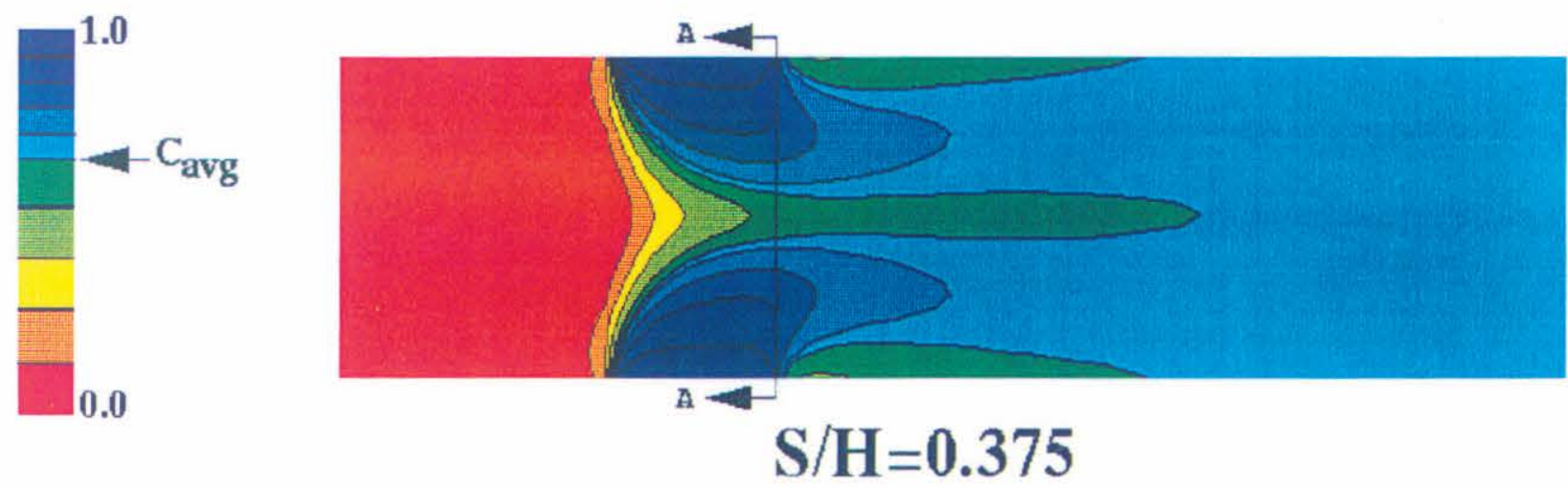

2.0
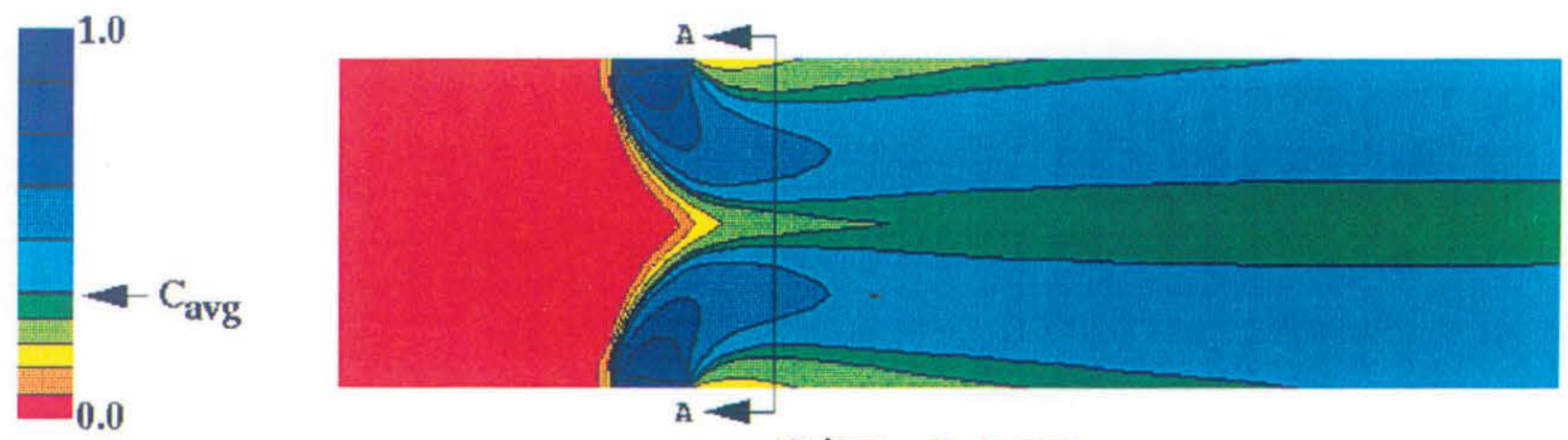

0.50

\section{$\mathrm{S} / \mathrm{H}=\mathbf{0 . 2 7 5}$}
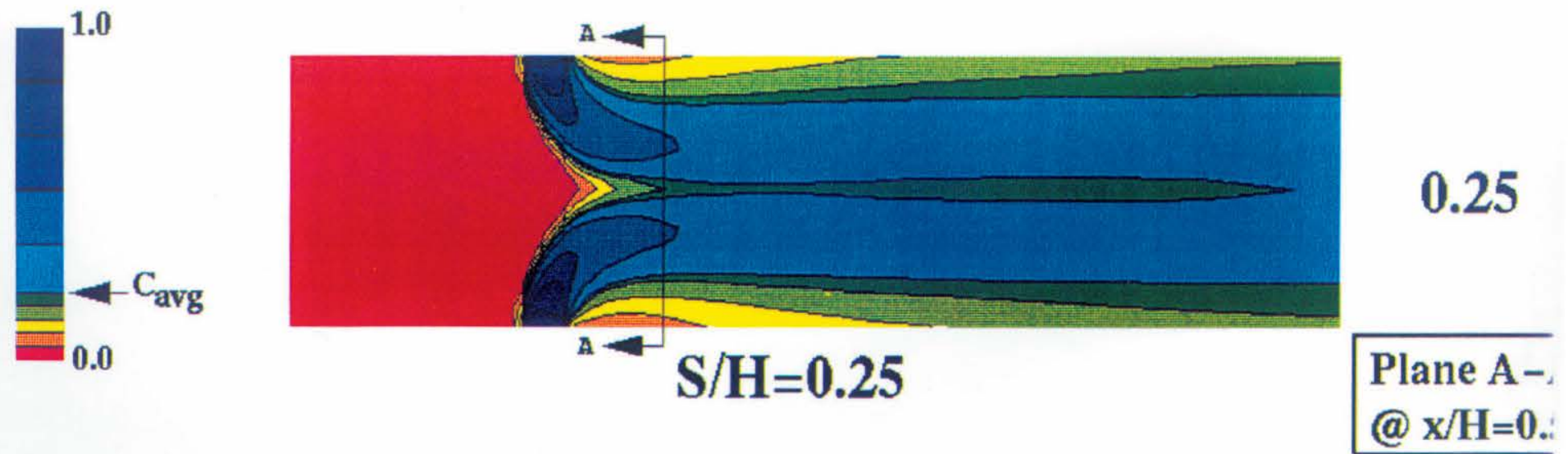

Figure 7. Effect of Jet-to-Mainstream Mass Flow Variation on Jet Penetration at Optimum S/H: $J=36, L / W=4$ 


\section{Axial Cross-Sections@x/H=0.50}
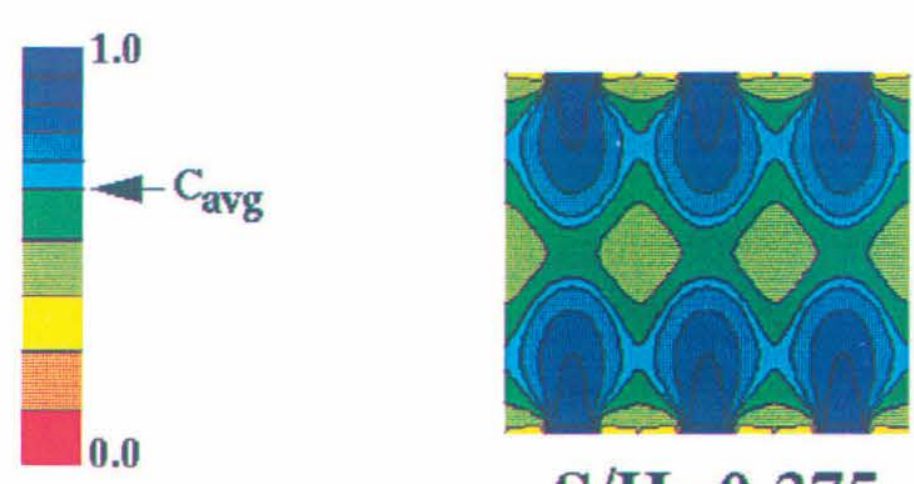

MR

\section{$\mathrm{S} / \mathrm{H}=\mathbf{0 . 3 7 5}$}

2.0
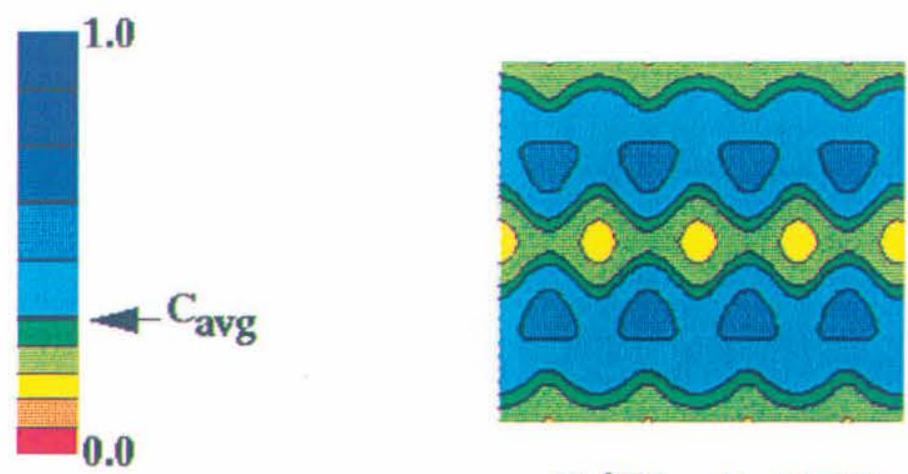

0.50

\section{$\mathrm{S} / \mathrm{H}=\mathbf{0 . 2 7 5}$}

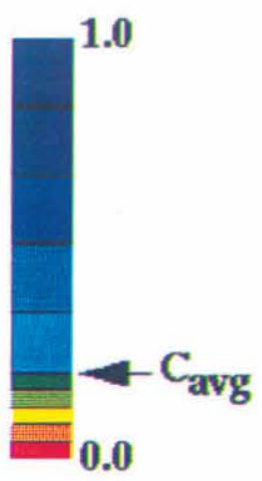

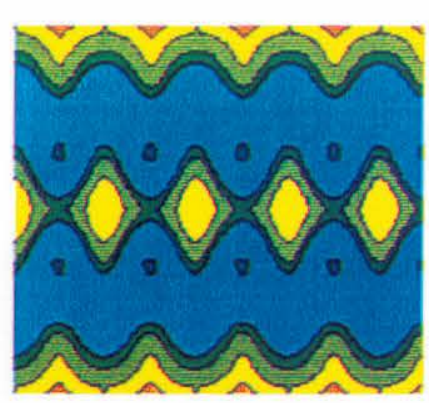

$\mathrm{S} / \mathrm{H}=\mathbf{0 . 2 5}$

Figure 8. Effect of Jet-to-Mainstream Mass Flow Ratio on Jet Penetration: $M R=2.0, J=36$ 


\section{Slot Centerline@ S/H=0.425}

Jet Mass

Fraction

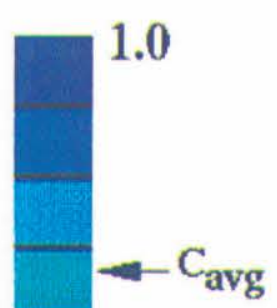

0.0

Plane A-A @ $\mathrm{x} / \mathrm{H}=\mathbf{0 . 5 0}$

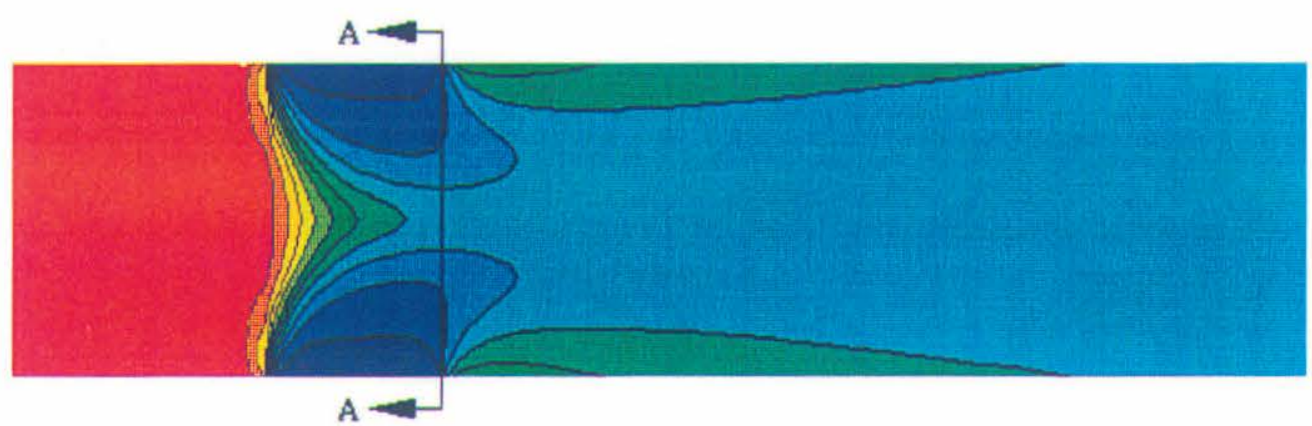

$A-$

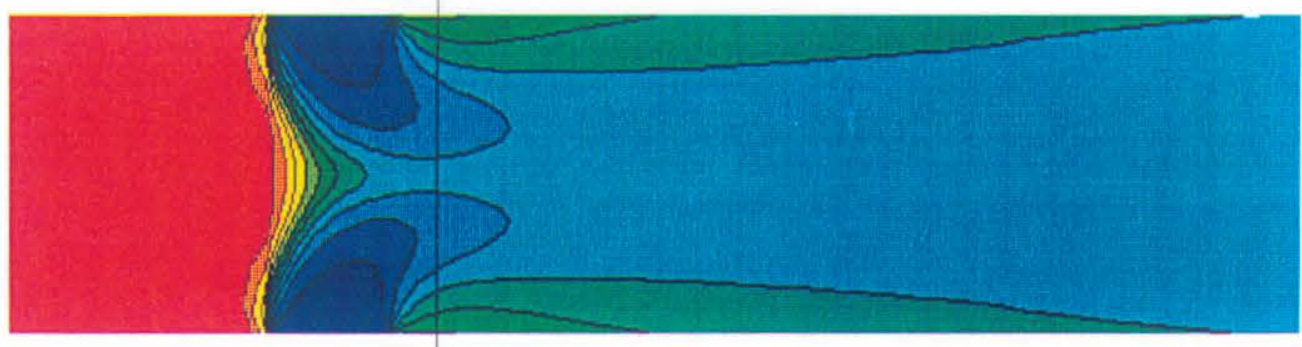

$A \rightarrow$

$A-1$

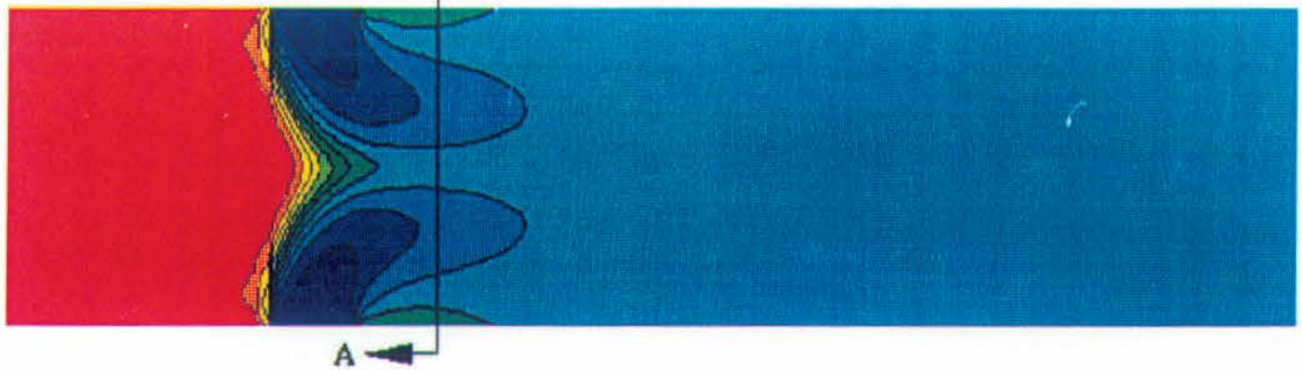

1

2

Circle

Figure 9. Effect of Aspect Ratio on Jet Penetration: $M R=2.0, J=36$ 


\section{Top Injection Plane @ $\mathrm{S} / \mathrm{H}=\mathbf{0 . 4 2 5}$}

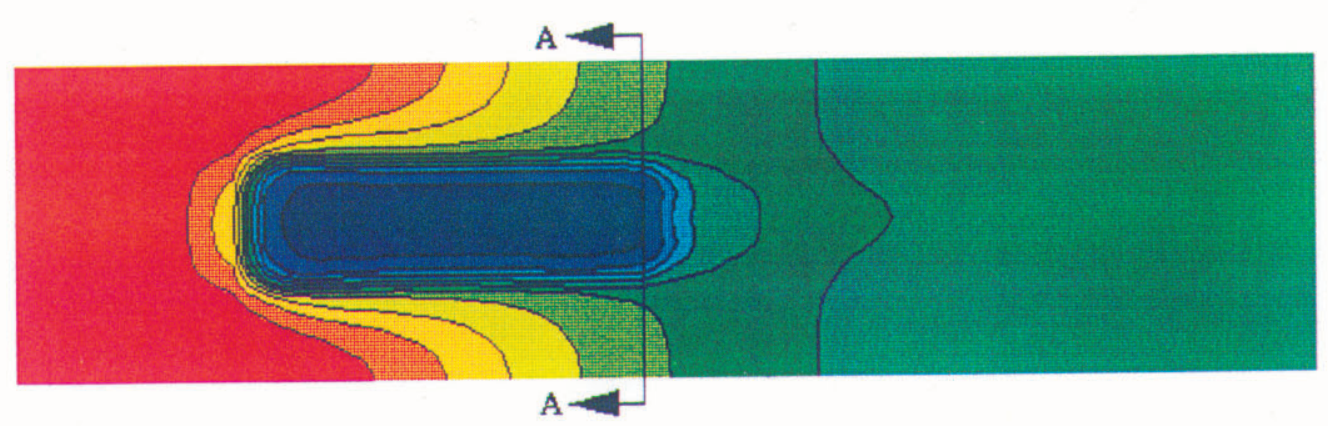

$\mathbf{L} / \mathbf{W}$

Jet

Mass

Fraction

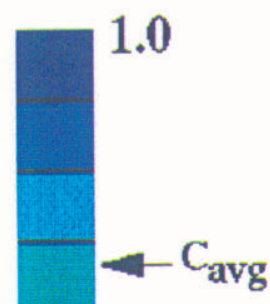

Jet Blockage 31\%

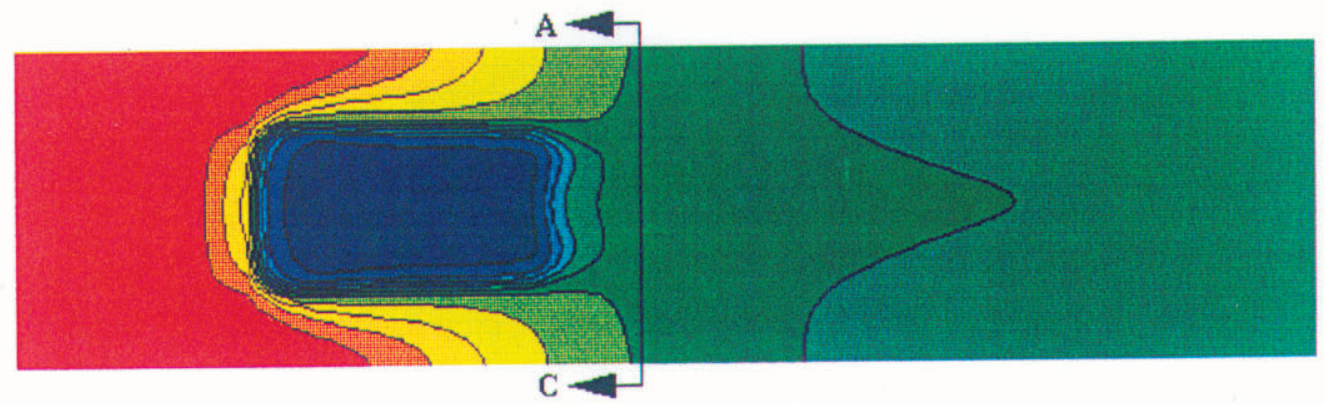

Jet Blockage $44 \%$

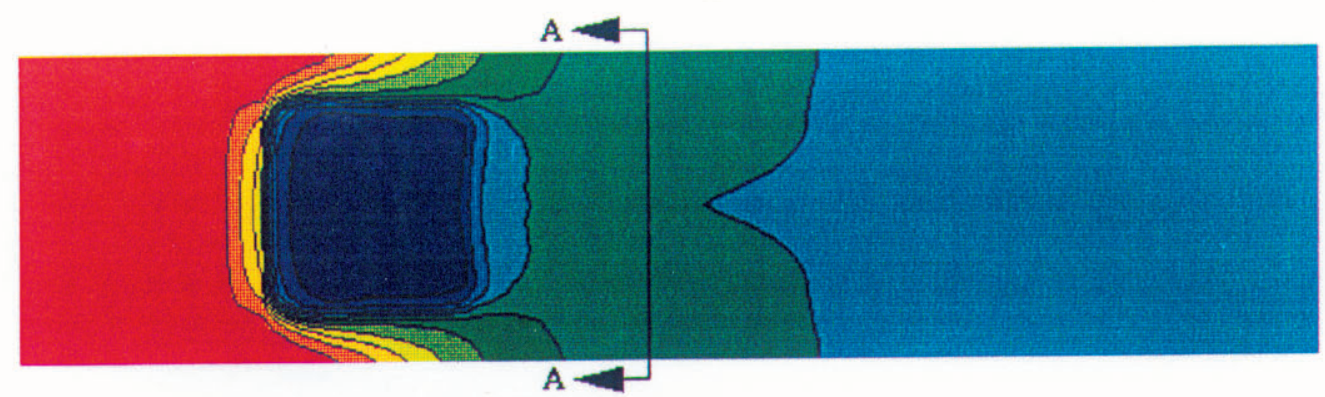

Jet Blockage 63\%

0.0

Plane A-A

(a) $\mathrm{x} / \mathrm{H}=\mathbf{0 . 5 0}$

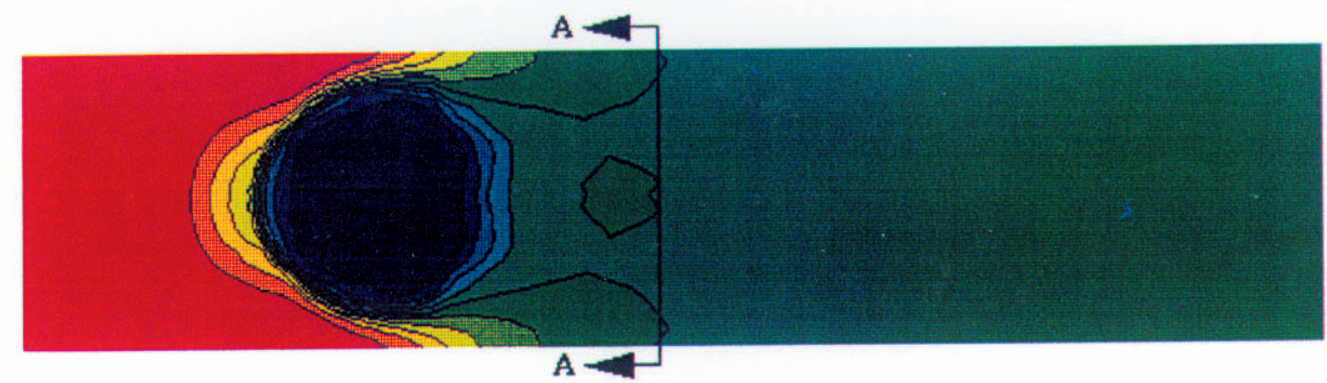

Circle

\section{Jet Blockage 71\%}

Figure 10. Effect of Aspect Ratio on Flow Characteristics at Top Wall: $M R=2.0, \mathrm{~J}=36$ 


\section{Top Injection Plane @S/H=0.425}

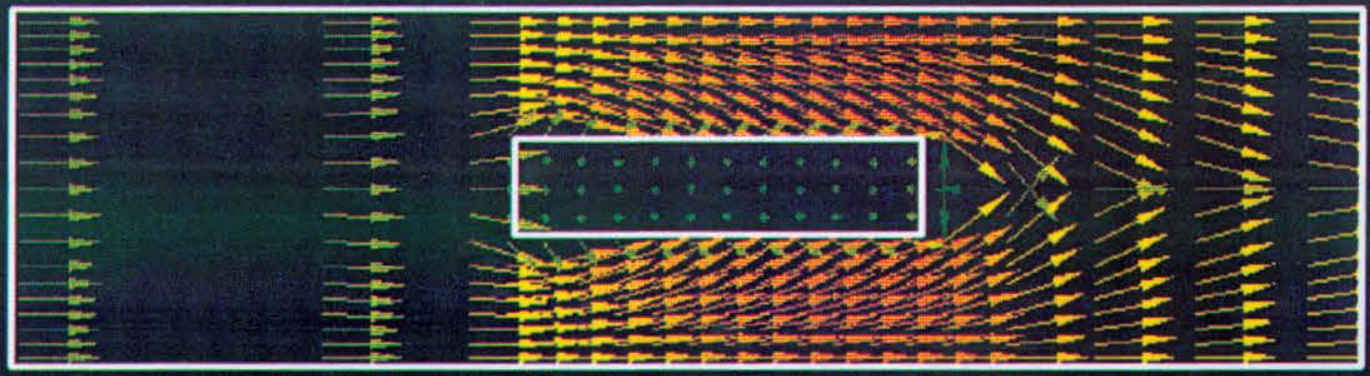

Velocity $(\mathrm{m} / \mathrm{sec})$

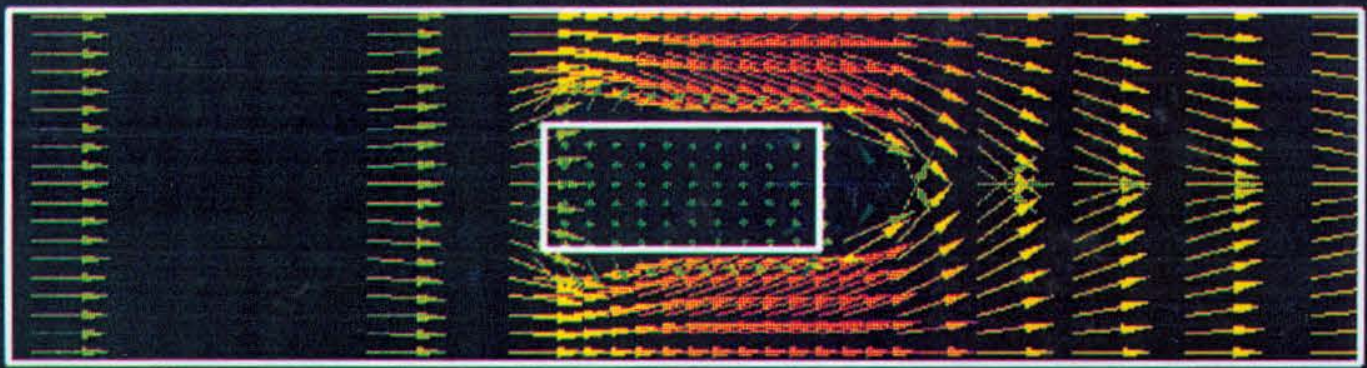

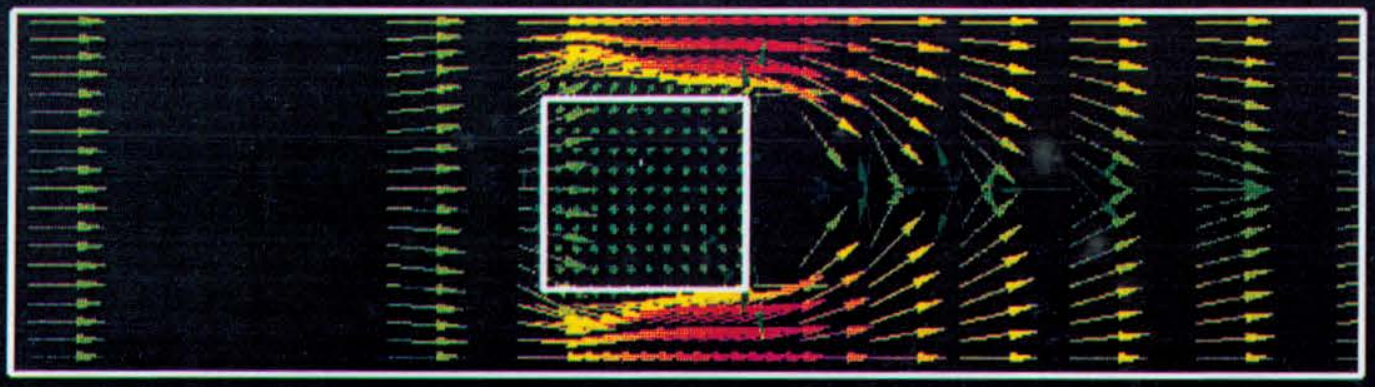

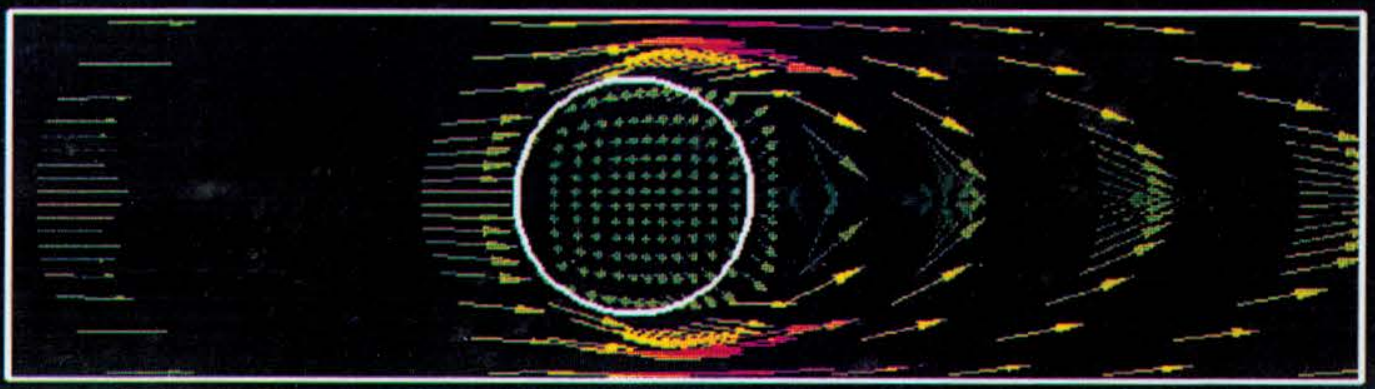

Circle

Figure 11. Effect of Aspect Ratio on Jet Wakes: $M R=2.0, J=36$ (Every $2^{\text {nd }}$ Vector Shown) 


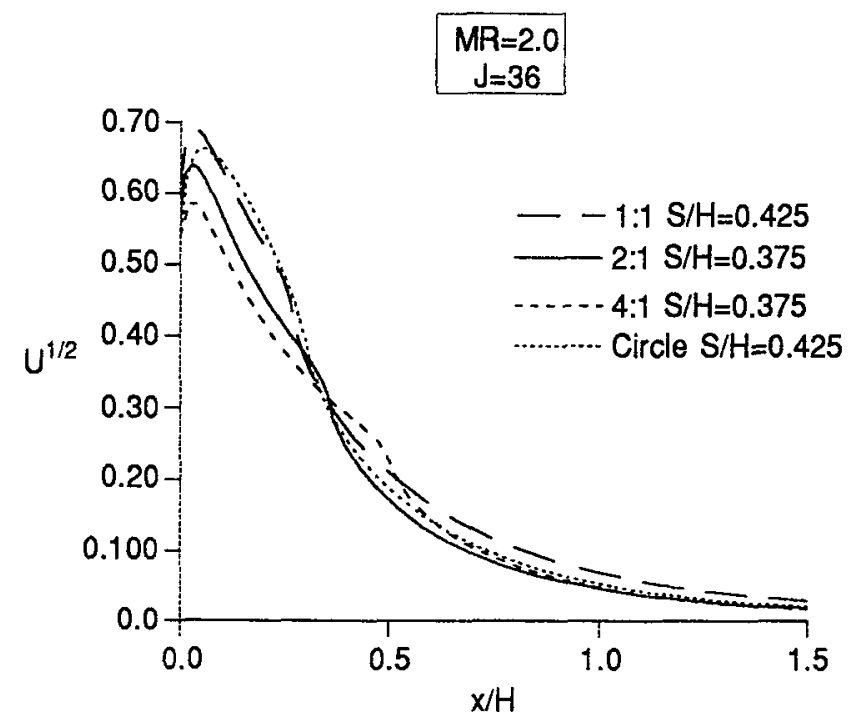

Figure 12. Effect of Aspect Ratio on Unmixedness 


\section{Axial Cross-Sections @ x/H=0.50}

$\underline{\mathbf{L}} \mathbf{W}$

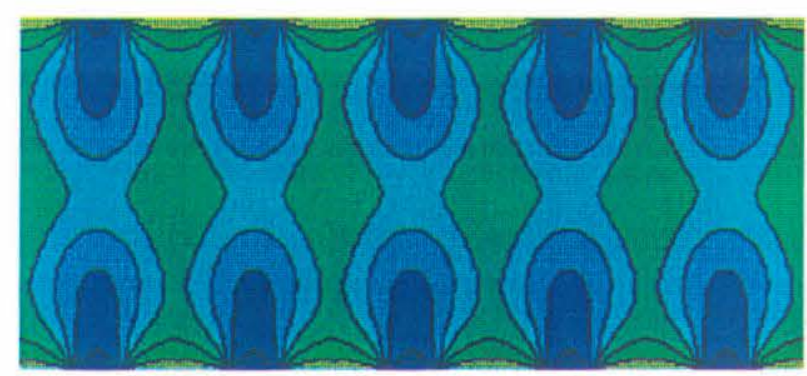

4

Jet

Mass

Fraction
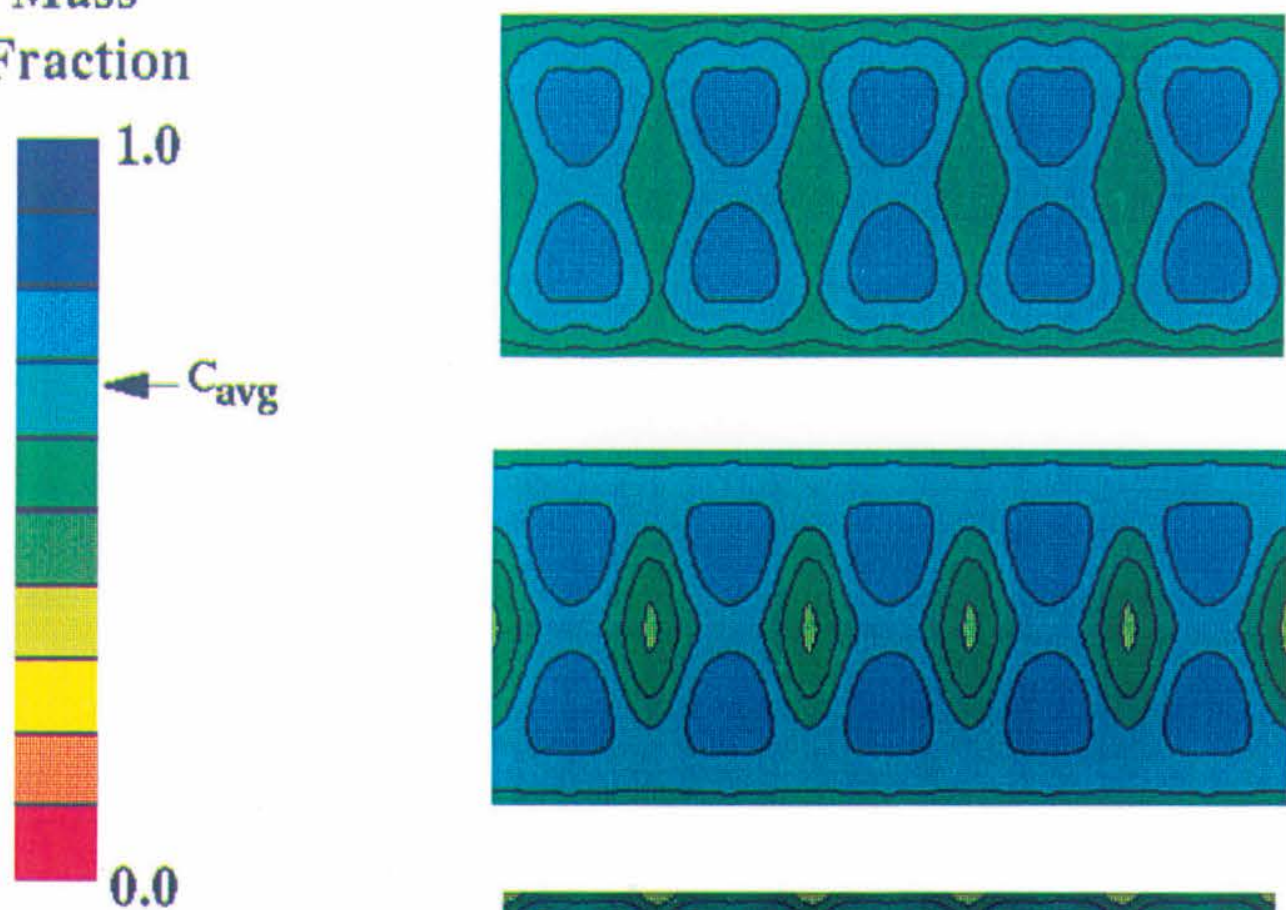

2

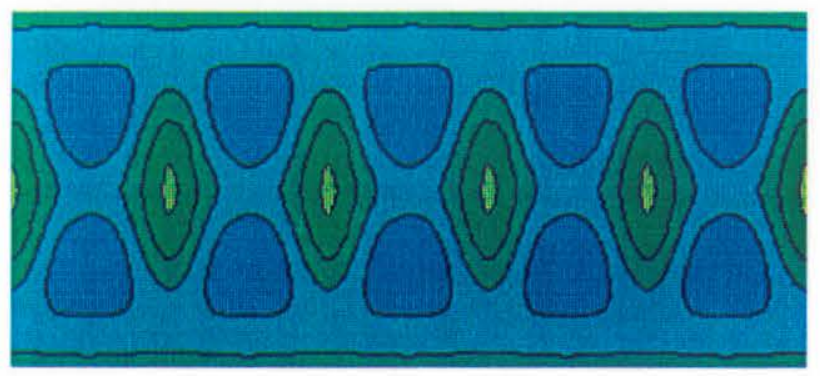

1

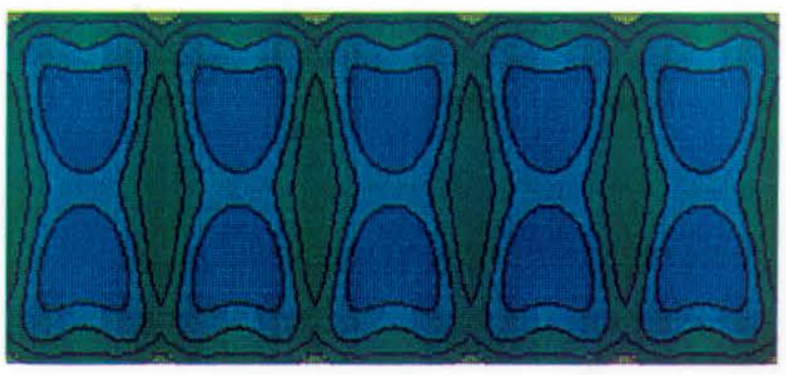

\section{Circle}

\section{$\mathrm{S} / \mathrm{H}=\mathbf{0 . 4 2 5}$}

Figure 13. Effect of Aspect Ratio on Jet Penetration: $M R=2.0, J=36$ 


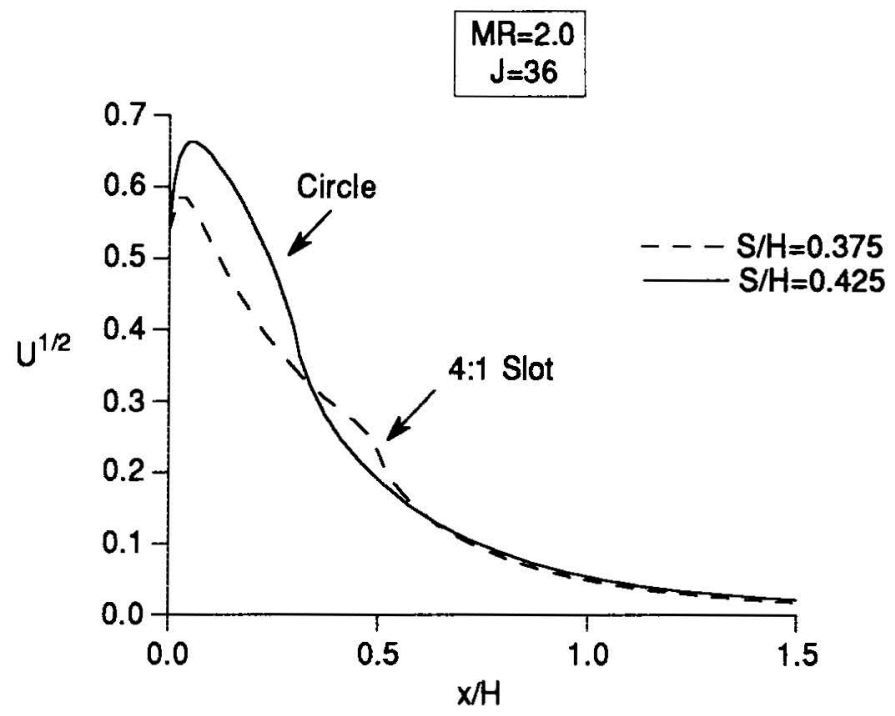

Figure 14. Unmixedness Comparison of 4:1 Slot and Circle at Optimum S/H 
Public reporting burden for this collection of information is estimated to average 1 hour per response, including the time for reviewing instructions, searching existing data sources, gathering and maintaining the data needed, and completing and reviewing the collection of information. Send comments regarding this burden estimate or any other aspect of this collection of information, including suggestions for reducing this burden, to Washington Headquarters Services, Directorate for Information Operations and Reports, 1215 Jefferson Davis Highway, Suite 1204, Arlington, VA 22202-4302, and to the Office of Management and Budget, Paperwork Reduction Project (0704-0188), Washington, DC 20503.

\begin{tabular}{|l|l|l}
\hline 1. AGENCY USE ONLY (Leave blank) & $\begin{array}{c}\text { 2. REPORT DATE } \\
\text { January } 1994\end{array}$ & $\begin{array}{r}\text { 3. REPORT TYPE AND DATES COVERED } \\
\text { Technical Memorandum }\end{array}$ \\
\hline
\end{tabular}

\section{TITLE AND SUBTITLE}

5. FUNDING NUMBERS

CFD Assessment of Orifice Aspect Ratio and Mass Flow Ration on Jet Mixing in Rectangular Ducts

6. AUTHOR(S)

WU-537-02-21-00

D.B. Bain, C.E. Smith, and J.D. Holdeman

7. PERFORMING ORGANIZATION NAME(S) AND ADDRESS(ES)

National Aeronautics and Space Administration

Lewis Research Center

Cleveland, Ohio 44135-3191

8. PERFORMING ORGANIZATION

REPORT NUMBER

E-8276

9. SPONSORING/MONITORING AGENCY NAME(S) AND ADDRESS(ES)

National Aeronautics and Space Administration

Washington, DC 20546-0001

10. SPONSORING/MONITORING

AGENCY REPORT NUMBER

NASA TM-106434

AIAA-94-0218

\section{SUPPLEMENTARY NOTES}

Prepared for the 32nd Aerospace Sciences Meeting and Exhibit, sponsored by the American Institue of Aeronautics and Astronautics, Reno, Nevada, January 10-13, 1994. D.B. Bain and C.E. Smith, CFD Research Corporation, Huntsville, Alabama, (work funded by NASA contract NAS3-25967); J.D. Holdeman, NASA Lewis Research Center. Responsible person, J.D. Holdeman, (216) 433-5846.

12a. DISTRIBUTION/AVAILABILITY STATEMENT

12b. DISTRIBUTION CODE

Unclassified - Unlimited

Subject Category: 07

Available electronically at http://gltrs.grc.nasa.gov/GLTRS

This publication is available from the NASA Center for AeroSpace Information, (301) 621-0390.

13. ABSTRACT (Maximum 200 words)

Isothermal CFD analysis was performed on axially opposed rows of jets mixing with crossflow in a rectangular duct.

Laterally, the jets' centerlines were aligned with each other on the top and bottom walls. The focus of this study was to characterize the effects of orifice aspect ratio and jet-to-mainstream mass flow ratio on jet penetration and mixing. Orifice aspect ratios (L/W) of 4-to-1, 2-to-1, and 1-to-1, along with circular holes, were parametrically analyzed. Likewise, jet-to-mainstream mass flow ratios (MR) of 2.0, 0.5 , and 0.25 were systematically investigated. The jet-to-mainstream momentum-flux ratio $(\mathrm{J})$ was maintained at 36 for all cases, and the orifice spacing-to-duct height $(\mathrm{S} / \mathrm{H})$ was varied until optimum mixing was attained for each configuration. The numerical results showed that orifice aspect ratio (and likewise orifice blockage) had little effect on jet penetration and mixing. Based on mixing characteristics alone, the 4-to-1 slot was comparable to the circular orifice. The 4-to-1 slot has a smaller jet wake which may be advantageous for reducing emissions. However, the axial length of a 4-to-1 slot may be prohibitively long for practical application, especially for MR of 2.0. The jet-to-mainstream mass flow ratio had a more significant effect on jet penetration and mixing. For a 4-to-1 aspect ratio orifice, the design correlating parameter for optimum mixing $[\mathrm{C}=(\mathrm{S} / \mathrm{H}) \sqrt{ }]$ varied from 2.25 for a mass flow ratio of 2.0 to 1.5 for a mass flow ratio of 0.25 .

14. SUBJECT TERMS

Dilution; Jet mixing flow; Gas turbine; Combustion chamber; Emissions 15. NUMBER OF PAGES 37 16. PRICE CODE A03

\begin{tabular}{|c|c|c|}
\hline $\begin{array}{c}\text { 17. SECURITY CLASSIFICATION } \\
\text { OF REPORT } \\
\text { Unclassified }\end{array}$ & $\begin{array}{c}\text { 18. SECURITY CLASSIFICATION } \\
\text { OF THIS PAGE } \\
\text { Unclassified }\end{array}$ & $\begin{array}{c}\text { 19. SECURITY CLASSIFICATION } \\
\text { OF ABSTRACT } \\
\text { Unclassified }\end{array}$ \\
\hline
\end{tabular}




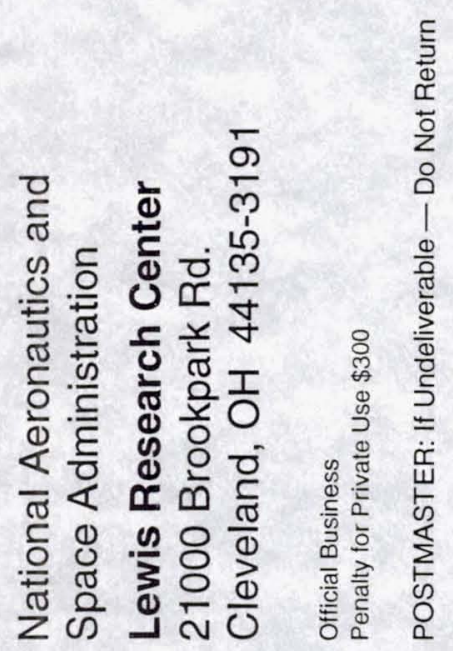

